Article

\title{
Suzuki-Miyaura Coupling Using Monolithic Pd Reactors and Scaling-Up by Series Connection of the Reactors
}

\author{
Aiichiro Nagaki ${ }^{1, *}$, Katsuyuki Hirose ${ }^{1}$, Yuya Moriwaki ${ }^{1}$, Masahiro Takumi ${ }^{1}$, \\ Yusuke Takahashi ${ }^{1}$, Koji Mitamura ${ }^{2}$, Kimihiro Matsukawa ${ }^{2}$, Norio Ishizuka ${ }^{3}$ and \\ Jun-ichi Yoshida 4,*(D) \\ 1 Department of Synthetic Chemistry and Biological Chemistry, Graduate School of Engineering, \\ Kyoto University, Nishikyo-ku, Kyoto 615-8510, Japan; hirose.kp@om.asahi-kasei.co.jp (K.H.); \\ y_moriwaki@kyoeisha.co.jp (Y.M.); takumi@sbchem.kyoto-u.ac.jp (M.T.); \\ takahashiy@sbchem.kyoto-u.ac.jp (Y.T.) \\ 2 Osaka Municipal Technical Research Institute, Electronic Material Research Division, 1-6-50, Morinomiya, \\ Joto-ku, Osaka 536-8553, Japan; mitamura@omtri.or.jp (K.M.); kimihiro_matsukawa@accelsrt.jp (K.M.) \\ 3 Emaus Kyoto Inc. R\&D, 26 Nishida-cho, Saiin, Ukyo-ku, Kyoto 615-0055, Japan; norio@emaus-kyoto.com \\ 4 National Institute of Technology, Suzuka College, Shiroko-cho, Suzuka, Mie 510-0294, Japan \\ * Correspondence: anagaki@sbchem.kyoto-u.ac.jp (A.N.); j-yoshida@jim.suzuka-ct.ac.jp (J.-i.Y.)
}

Received: 2 March 2019; Accepted: 19 March 2019; Published: 25 March 2019

check for updates

\begin{abstract}
The space integration of the lithiation of aryl halides, the borylation of aryllithiums, and Suzuki-Miyaura coupling using a Pd catalyst supported by a polymer monolith flow reactor without using an intentionally added base was achieved. To scale up the process, a series connection of the monolith $\mathrm{Pd}$ reactor was examined. To suppress the increase in the pressure drop caused by the series connection, a monolith reactor having larger pore sizes was developed by varying the temperature of the monolith preparation. The monolithic Pd reactor having larger pore sizes enabled Suzuki-Miyaura coupling at a higher flow rate because of a lower pressure drop and, therefore, an increase in productivity. The present study indicates that series connection of the reactors with a higher flow rate serves as a good method for increasing the productivity without decreasing the yields.
\end{abstract}

Keywords: flow synthesis; monolith reactors

\section{Introduction}

Recently the chemical synthesis using continuous flow reactors has received significant research interests from both academia and the industry [1-47]. Because of better heat and mass transfer and a shorter residence time, flow processes offer various benefits over conventional batch processes, including increased controllability, safety, and selectivity. A number of synthetic transformations that are difficult or impossible for conventional batch processes have been developed using flow processes [48-58].

Palladium-catalyzed cross-coupling reactions [59-64], in particular, using heterogeneous catalysts [65-69], serve as a powerful method for the chemical production of fine chemicals and pharmaceuticals, and several examples of the flow process using supported palladium catalysts [70-87] including the Suzuki-Miyaura coupling of arylboronic acids and aryl halides [88-91] have been reported. Although some arylboronic acids are commercially available, it is often necessary to prepare appropriate arylboronic acids for a desired transformation [92-99], and the preparation of arylbornonic acids often suffers from difficulties in the purification processes [100-105]. Therefore, the integration 
of the preparation of boronic acids and the Suzuki-Miyaura coupling improves the efficiency of the overall transformation. Recently, Buchwald et al. reported the space integration of the preparation of boronic esters by lithiation, borylation, and Suzuki-Miyaura coupling [106]. We have also reported the space integration of the preparation of arylboronic esters bearing electrophilic functional groups based on flash chemistry [107-112] using flow microreactors [113]. The overall transformation enables the cross-coupling of two aryl halides bearing electrophilic functional groups. However, homogeneous Pd catalysts are used in both processes. Therefore, it was highly desirable to develop a similar process using heterogeneous $\mathrm{Pd}$ catalysts which enable the easy separation and recycling of the catalyst.

Polymer monoliths [114-119] serve as ideal supports for reagents and catalysts for continuous flow processes because of their high controllability of surface properties associated with the formation of nano-, micro-, and mesoporous structures. The contact time and temperature can be spatially and temporally controlled throughout the channels. In a preliminary communication, we reported that the space integration [120-122] of the preparation of arylboronic esters and Suzuki-Miyaura coupling using a flow reactor packed with the polymer monolith containing an immobilized Pd catalyst [123]. Herein, we report the full details of this study and the process by the series connection of the reactors with high flow rates (Scheme 1).

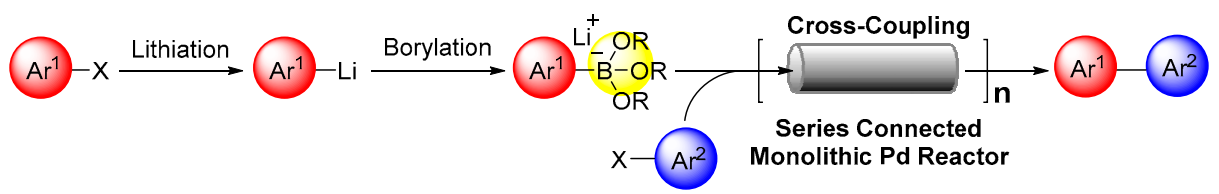

Scheme 1. The space integration of the preparation of arylboronic esters and Suzuki-Miyaura coupling by the series connection of a flow reactor packed with the polymer monolith containing an immobilized Pd catalyst.

\section{Results and Discussion}

\subsection{Preparation of Lithium Arylborates Using Flow Microreactors}

Prior to studying the Suzuki-Miyaura coupling, we studied the preparation of lithium arylborates by the lithiation of aryl halides followed by the borylation of aryllithiums [113]. The reactions were carried out using a flow microreactor system consisting of two T-shaped micromixers (M1 and M2) and two microtube reactors (R1 and R2) (Figure 1). For example, a solution of bromobenzene $(0.10 \mathrm{M}$ in THF, $6.0 \mathrm{~mL} / \mathrm{min})$ and a solution of $n-B u L i ~(0.60 \mathrm{M}$ in hexane, $1.0 \mathrm{~mL} / \mathrm{min})$ were introduced to M1 $(\phi=500 \mu \mathrm{m})$ at $0{ }^{\circ} \mathrm{C}$ by syringe pumps. The resulting solution was passed through $\mathbf{R} \mathbf{1}(\phi=1000 \mu \mathrm{m}$, $\left.\mathrm{L}=25 \mathrm{~cm}\left(t^{\mathrm{R} 1}=1.7 \mathrm{~s}\right)\right)$ and was mixed with a solution of trimethoxyborane $(0.12 \mathrm{M}$ in THF, $5.0 \mathrm{~mL} / \mathrm{min})$ in $\mathbf{M} 2(\phi=500 \mu \mathrm{m})$. The resulting solution was then passed through $\mathbf{R} 2(\phi=1000 \mu \mathrm{m}, \mathrm{L}=50 \mathrm{~cm}$ $\left.\left(t^{R 2}=2.0 \mathrm{~s}\right)\right)$. A cloudy mixture was obtained, presumably because of an insufficient solubility of the resulting lithium arylborate (Figure 2a). Various solvents including THF, methanol, and ethanol were examined to solubilize the lithium arylborate, and a clear solution was obtained when methanol was added (Figure 2b).

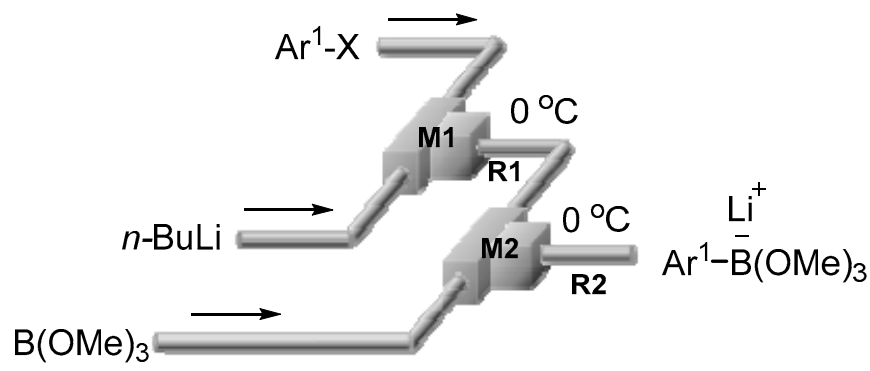

Figure 1. The flow microreactor system for the lithiation of bromobenzene $\left(\mathrm{Ar}^{1} \mathrm{X}\right)$ and for borylation (micromixers: $\mathbf{M} 1$ and $\mathbf{M} 2$, microtube reactors: $\mathbf{R} 1$ and $\mathbf{R} 2$ ). 


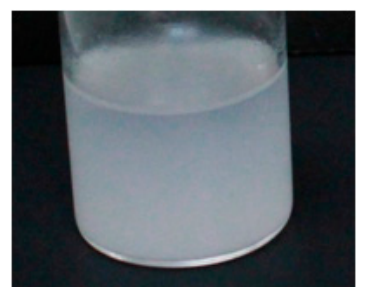

(a)

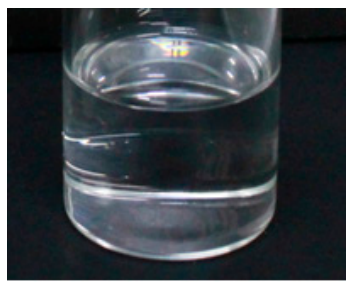

(b)

Figure 2. A solution of lithium trimethoxy(phenyl)borate (a) before the addition of methanol and (b) after the addition of methanol.

\subsection{Preparation of Polymer Monolith and Immobilization of Pd Catalyst}

The preparation of a polymer monolith and the immobilization of a Pd catalyst were carried out as follows (Figure 3). 1,3-Bis( $N, N$-diglycidylaminomethyl)cyclohexane was added to a solution of poly(ethylene glycol) (PEG, molecular mass = 200), 4,4'-diaminodicyclohexyl-methane, and 6-(phenylamino)-1,3,5-triazine-2,4-dithiol, and the mixture was stirred at room temperature for $30 \mathrm{~min}$. The resultant homogeneous solution was poured into a cylindrical stainless-steel reactor (an empty HPLC column, $4.6 \mathrm{~mm}$ ID $\times 150 \mathrm{~mm}$ length). The reactor was annealed to produce epoxy monolithic gels inside. Polymer monolith A was produced by annealing at $100{ }^{\circ} \mathrm{C}$, whereas polymer monolith B was produced by annealing at $85{ }^{\circ} \mathrm{C}$ (vide infra). The gelation occurred within $30 \mathrm{~min}$, and the samples were aged at the same temperature for a day. The resulting epoxy monoliths were washed with tetrahydrofuran by using an HPLC pump at $0.1 \mathrm{~mL} / \mathrm{min}$ for an hour and dried under a vacuum. As shown in Figure 4, the pore size of the gel depends on the annealing temperature. The pore size of monolith $\mathbf{B}$ was larger than that of monolith $\mathbf{A}$. Then, monolith $\mathbf{A}$ and $\mathbf{B}$ were treated with a solution of palladium acetate and were reduced with sodium borohydride. The resulting monolith reactors containing the Pd catalyst were used for Suzuki-Miyaura coupling.

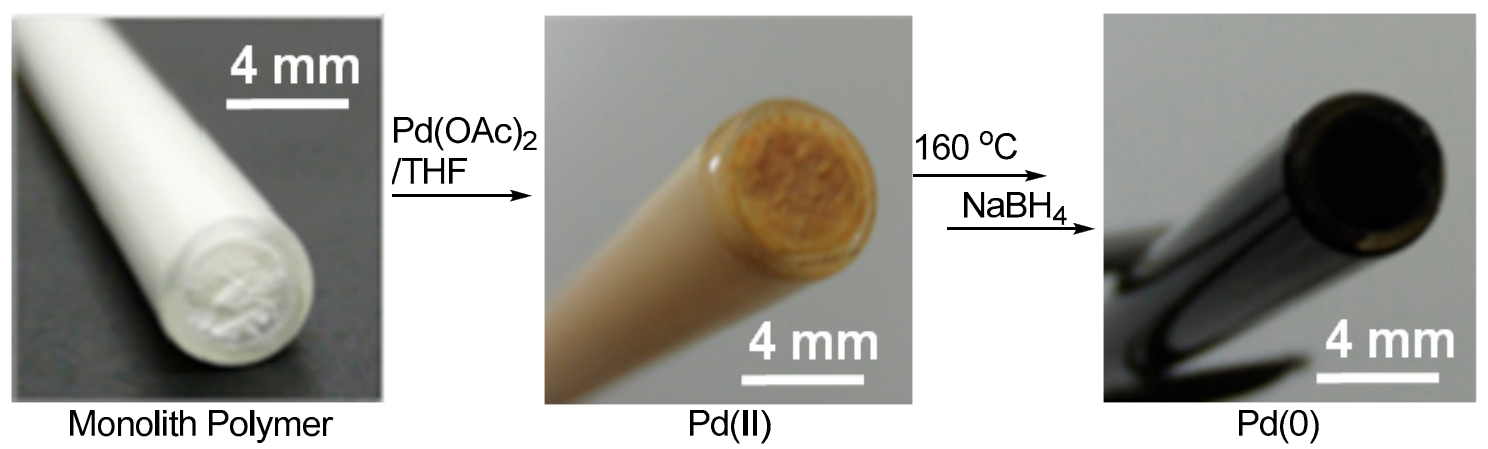

Figure 3. The immobilization of Pd on the polymer monolith in a flow reactor.

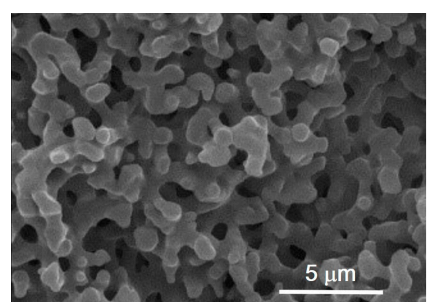

(a)

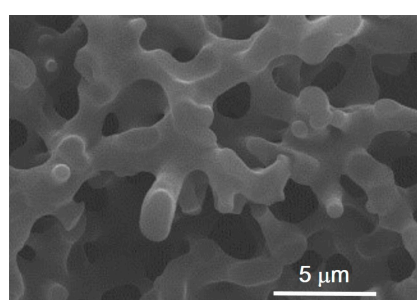

(b)

Figure 4. Cont. 


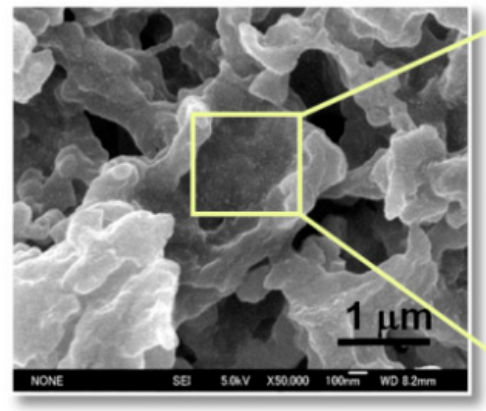

(c)
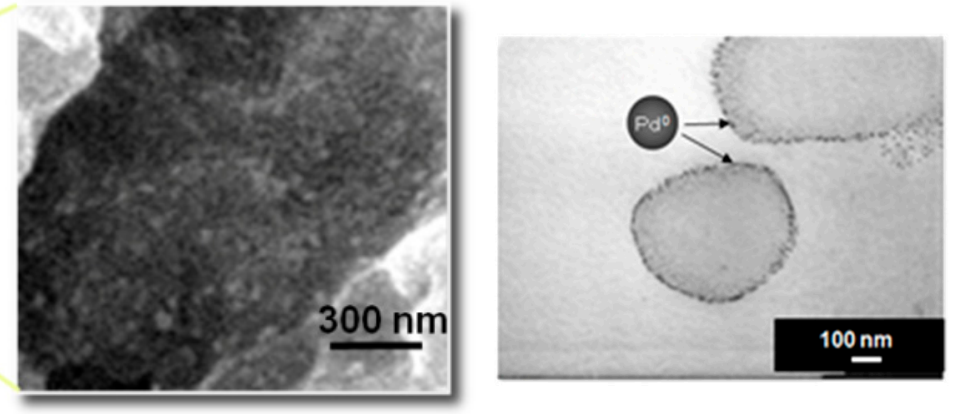

(d)

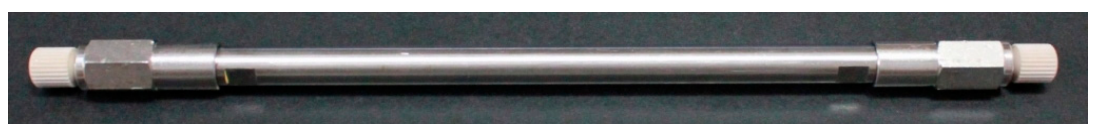

(e)

Figure 4. (a) A SEM image of monolith A before treatment with $\mathrm{Pd}(\mathrm{OAc})_{2}$, (b) a SEM image of monolith $\mathbf{B}$ before treatment with $\mathrm{Pd}(\mathrm{OAc})_{2}$, (c) a SEM image of monolith $\mathbf{A}$ after treatment with $\mathrm{Pd}(\mathrm{OAc})_{2}$ followed by a reduction with $\mathrm{NaBH}_{4},(\mathbf{d})$ a TEM image of the cross section of monolith $\mathbf{A}$, and (e) an appearance of the flow reactor containing the Pd catalyst supported by the monolith (size: $4.6 \mathrm{~mm}$ ID $\times 150 \mathrm{~mm}$ length).

\subsection{Suzuki-Miyaura Coupling Using the Pd Catalyst Supported by Polymer Monolith A}

Next, we examined the reaction integration of the lithiation of bromobenzene $\left(\mathrm{Ar}^{1}-\mathrm{X}: \mathrm{Ar}^{1}=\mathrm{C}_{6} \mathrm{H}_{5}-\right.$, $\mathrm{X}=\mathrm{Br}$ ), the arylation of phenyllithiums, and the Suzuki-Miyaura coupling with $p$-iodobenzonitrile (Figure 5). To the resulting solution of lithium trimethoxy(phenyl)borate was added a solution of $p$-iodobenzonitrile $\left(\mathrm{Ar}^{2}-\mathrm{X}: \mathrm{Ar}^{2}=p-\mathrm{NC} \mathrm{C}_{6} \mathrm{H}_{4}-, \mathrm{X}=\mathrm{I}\right)(0.033 \mathrm{M}$ in $\mathrm{MeOH})$, and the mixture was passed through the reactor containing the $\mathrm{Pd}$ catalyst supported by monolith $\mathbf{A}$ at $T^{\circ} \mathrm{C}$ using a plunger pump. The reactions were carried out with various residence times $\left(t^{\mathrm{R}}\right)$ in the monolith reactor and at various temperatures $(T)$. The residence times were estimated based on the void volume of the reactor.

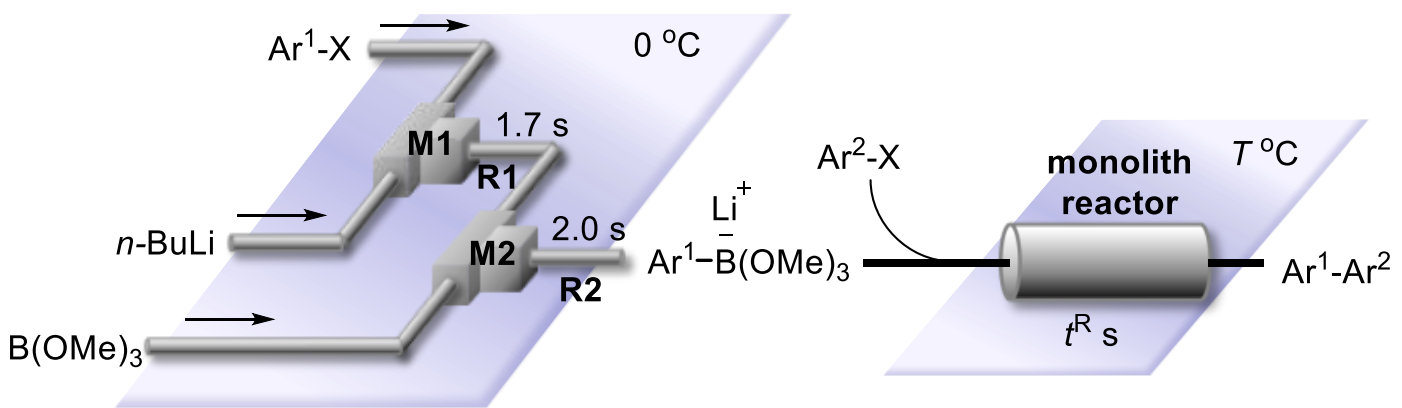

Figure 5. The flow microreactor system for lithiation, borylation, and Suzuki-Miyaura coupling using the Pd catalyst supported by the polymer monolith (micromixers: M1 and M2, microtube reactors: R1 and R2).

As profiled in Figure 6, the yield of biphenyl-4-carbonitrile was significantly influenced by both $T$ and $t^{\mathrm{R}}$. At $100{ }^{\circ} \mathrm{C}$, the yield increased with an increase in $t^{\mathrm{R}}$. The coupling product was obtained in good yields $(>93 \%)$ with $t^{\mathrm{R}}$ longer than $4.7 \mathrm{~min}$. The reaction at $120^{\circ} \mathrm{C}$ resulted in a slightly better yield $\left(t^{\mathrm{R}}=9.4 \mathrm{~min}\right.$, quantitative yield). Notably, the reaction was complete within a few minutes without using an intentionally added base. Thereafter, the reactions were carried out under two conditions: condition (a) $\left(T=100{ }^{\circ} \mathrm{C}, t^{\mathrm{R}}=4.7 \mathrm{~min}\right)$ and condition $(\mathrm{b})\left(T=120^{\circ} \mathrm{C}, t^{\mathrm{R}}=9.4 \mathrm{~min}\right)$ for the monolith A catalyst. 


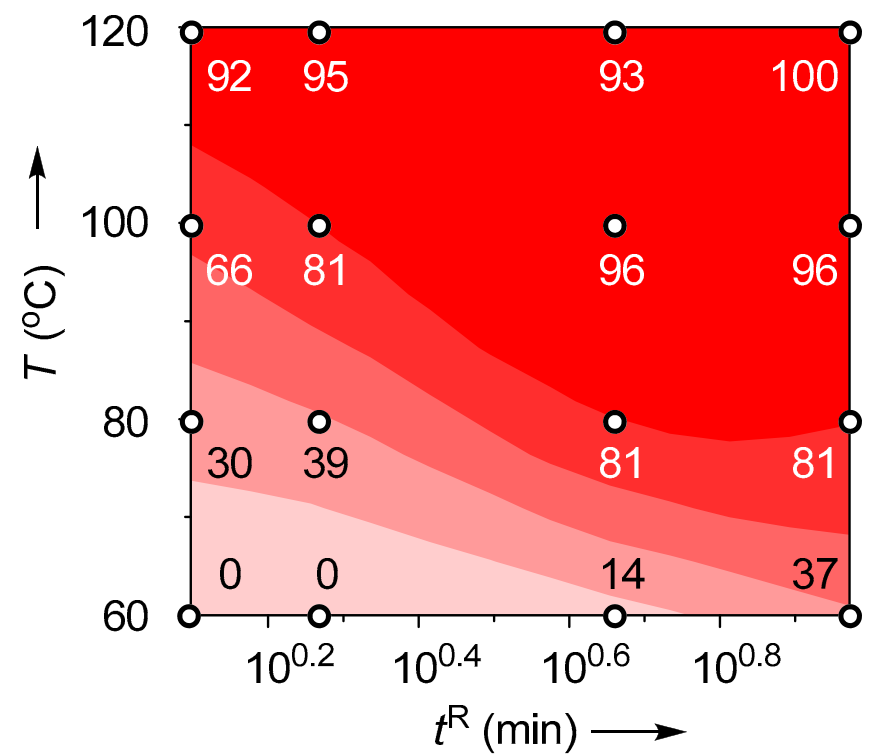

Figure 6. The temperature $(T)$-residence time $\left(t^{\mathrm{R}}\right)$ map for the cross-coupling of bromobenzene and $p$-bromobenzonitrile using the Pd catalyst supported by monolith A: the contour plots with a scattered overlay of the yields of biphenyl-4-carbonitrile (\%), which are indicated by small circles.

The present method was successfully applied to the cross-coupling of various functional aryl and heteroaryl iodides as coupling partners (Table 1). However, the use of phenyl iodide and aryl iodide having an electron-donating group resulted in much lower yields because the coupling reactions for these compounds were much slower. The use of substrates containing an ortho-substituent also showed a similar tendency. The yields for such reactions would be improved with a longer reaction time by connecting the reactors in serial. Notably, a cyano group tolerated the optimized conditions [124], although such functional groups easily undergo decomposition in conventional batch reactions. Therefore, biaryls bearing electrophilic functional groups on both aromatic rings can be synthesized in one flow. In addition, similar present transformations via lithiated heteroaromatics also took place effectively to give the corresponding heterobiaryls in good yields. Furthermore, a triaryl compound having one bromine atom on one of the aromatic rings was also synthesized via the lithiation of $4,4^{\prime}$-dibromobiphenyl, although such a transformation is very difficult when using conventional batch reactors because of the formation of a significant amount of dilithiated species [125].

Table 1. The cross-coupling of $\mathrm{Ar}^{1}-\mathrm{X}$ and $\mathrm{Ar}^{2}-\mathrm{X}$ using the polymer monolith $\mathrm{A}$ containing an immobilized Pd catalyst.

\begin{tabular}{|c|c|c|c|c|c|c|}
\hline \multirow{2}{*}{$\operatorname{Ar}^{1}-X$} & \multicolumn{2}{|c|}{$\begin{array}{c}\text { Conditions of } \\
\text { Lithiation and Borylation }\end{array}$} & \multirow{2}{*}{$A r^{2}-X$} & \multirow{2}{*}{ Product } & \multicolumn{2}{|c|}{ Yield (\%) ${ }^{a}$} \\
\hline & $\begin{array}{l}t^{\mathrm{R} 1} \\
(\mathrm{~s})\end{array}$ & $\begin{array}{c}\text { Temperature } \\
\left({ }^{\circ} \mathrm{C}\right)\end{array}$ & & & $\begin{array}{l}\text { Condition } \\
\text { (a) }{ }^{c}\end{array}$ & $\begin{array}{l}\text { Condition } \\
\text { (b) }{ }^{d}\end{array}$ \\
\hline$\geqslant-\mathrm{Br}$ & 1.7 & 0 & & & 96 & 100 \\
\hline & 1.7 & 0 & & & 0 & 3 \\
\hline & 1.7 & 0 & & & 76 & 87 \\
\hline & 1.7 & 0 & & & 6 & 41 \\
\hline & 1.7 & 0 & & & 1 & 29 \\
\hline & 1.7 & 0 & & & 86 & 92 \\
\hline
\end{tabular}


Table 1. Cont.

\begin{tabular}{|c|c|c|c|c|c|c|}
\hline \multirow{2}{*}{$\operatorname{Ar}^{1}-X$} & \multicolumn{2}{|c|}{$\begin{array}{c}\text { Conditions of } \\
\text { Lithiation and Borylation }\end{array}$} & \multirow{2}{*}{$A r^{2}-X$} & \multirow{2}{*}{ Product } & \multicolumn{2}{|c|}{ Yield $(\%)^{a}$} \\
\hline & $\begin{array}{l}t^{\mathrm{R} 1} \\
(\mathrm{~s})\end{array}$ & $\begin{array}{c}\text { Temperature } \\
\left({ }^{\circ} \mathrm{C}\right)\end{array}$ & & & $\begin{array}{l}\text { Condition } \\
\text { (a) }{ }^{c}\end{array}$ & $\begin{array}{l}\text { Condition } \\
\text { (b) } d\end{array}$ \\
\hline & 0.059 & 0 & & & 68 & 91 \\
\hline & 0.059 & 0 & & & 17 & 83 \\
\hline & 0.059 & 0 & & & 12 & 91 \\
\hline & 0.059 & 0 & & & 34 & 84 \\
\hline & 0.059 & 0 & & & 63 & 97 \\
\hline & 0.059 & 0 & & & 15 & 87 \\
\hline & 0.059 & 24 & & & 63 & 98 \\
\hline & 0.059 & 24 & & & 2 & 52 \\
\hline & 0.059 & 0 & & & 0 & $54^{\mathrm{b}}$ \\
\hline & 1.7 & 0 & & & 83 & 94 \\
\hline & 1.7 & 0 & & & 78 & 87 \\
\hline & 1.7 & 0 & & & 71 & 86 \\
\hline
\end{tabular}

\subsection{Suzuki-Miyaura Coupling Using the Pd Catalyst Supported by Monolith B}

The operation of integrated systems consisting of multiple monolithic reactors in series at higher flow rates suffers from a high pressure drop. To solve this problem, a polymer monolith (monolith B) with wider pore sizes was synthesized by changing reaction temperatures when prepared (monolith A for temperature at $100{ }^{\circ} \mathrm{C}$ and monolith $\mathbf{B}$ for temperature at $85^{\circ} \mathrm{C}$ ) (vide supra). Generally, the pressure drop depends on the pore size. In fact, the pressure drop of monolith $\mathbf{A}$ of a smaller pore size was larger than that of monolith $\mathbf{B}$ of a larger pore size. For example, the operation using a monolith $\mathbf{A}$ reactor at $60^{\circ} \mathrm{C}$ with the flow rate of $1.5 \mathrm{~mL} / \mathrm{min}$ led to $8.2 \mathrm{~Pa}$, whereas that using a monolith $\mathbf{B}$ reactor lead to $0.8 \mathrm{~Pa}$.

Before studying the series connection of the reactors, the reaction using a single monolith $\mathbf{B}$ reactor was examined. To a solution of lithium trimethoxy(phenyl)borate prepared by the flow method (Figure 3) was added a solution of $p$-iodobenzonitrile $(0.033 \mathrm{M}$ in $\mathrm{MeOH})$, and the mixture was passed through a reactor containing a Pd catalyst supported by monolith B using a plunger pump (Figure 5). The reactions were carried out with various residence times $\left(t^{R}\right)$ at various temperatures $(T)$. As profiled in Figure 7, the yield of biphenyl-4-carbonitrile was significantly influenced by both $T$ and $t^{R}$. At $100{ }^{\circ} \mathrm{C}$, the yield increased with an increase in $t^{\mathrm{R}}$, and the reaction was complete within a few minutes. 


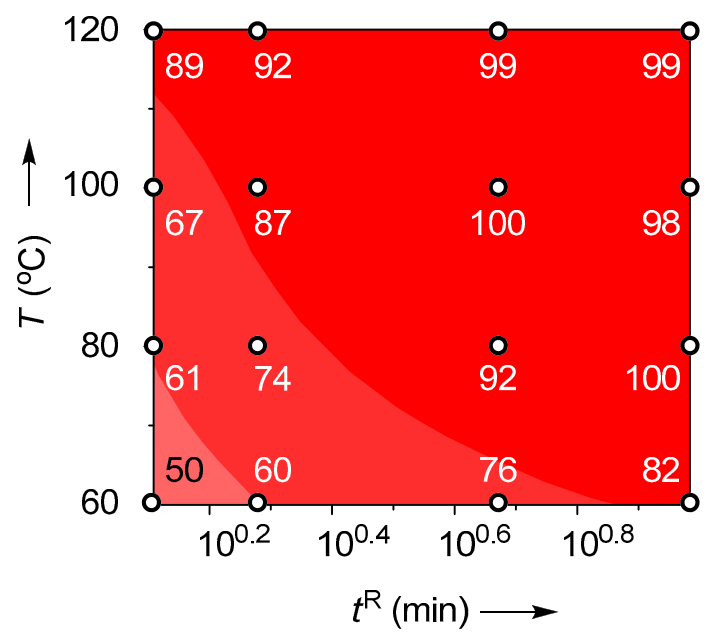

Figure 7. The temperature $(T)$-residence time $\left(t^{R}\right)$ map for the cross-coupling of bromobenzene and $p$-bromobenzonitrile using the Pd catalyst supported by monolith $\mathbf{B}$ : the contour plots with a scattered overlay of the yields of biphenyl-4-carbonitrile (\%), which are indicated by small circles.

\subsection{Series Connection}

In general, the productivity can be increased by increasing the flow rate in a single flow reactor (Figure 8a). However, the increase in the flow rate often causes a decrease in the conversion because the residence time in the reactor becomes shorter. Therefore, the numbering-up method with a parallel connection of the flow reactors serves as a common approach to improve the productivity [126-130] (Figure 8b). However, the method often suffers from a poor uniformity in fluid distribution [131,132]. Therefore, various types of flow distributors such as manifold- [133,134], bifurcation-, and split-and-recombine-type flow distributors have been developed to improve the uniformity of the fluid distribution.

(a)

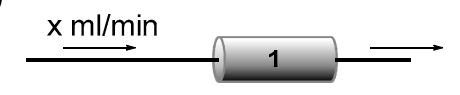

(b)

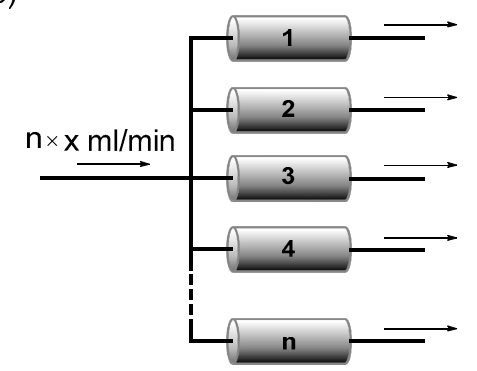

(c)

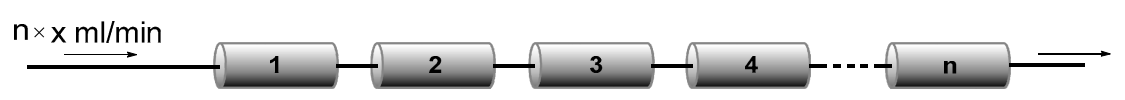

Figure 8. The increasing productivity of a continuous flow reaction keeping the residence time constant, (a) a single reactor, (b) the numbering-up by parallel connection of the reactors, and (c) the numbering-up by series connection of the reactors.

We envisaged that the numbering-up method with a series connection of the flow reactors [135] could serve as a method for increasing productivity (Figure 8c). The residence time can be kept constant by a series connection of the reactors even with higher flow rates. A major obstacle of this approach is, however, the increase in the pressure drop with an increase in the number of the reactors in the series. The use of the monolith $\mathbf{B}$ reactor solved the problem. Their use in series enabled operation at high flow rates with a low pressure drop. 
The reactions were carried out with various flow rates to control the residence time at $100{ }^{\circ} \mathrm{C}$ (Figure 9). When a single monolith A reactor was used, the yield of biphenyl-4-carbonitrile was significantly influenced by the flow rate (Table $2, \mathrm{n}=1$ ). The increase in the residence time by decreasing the flow rate caused an increase in the yield. The use of a single monolith $\mathbf{B}$ reactor also led to a similar result. Because of the larger pore size, the pressure drop for the monolith $\mathbf{B}$ reactor was much lower than that of the monolith $\mathbf{A}$ reactor. The product was obtained in a quantitative yield with the flow rate of $0.4 \mathrm{~mL} / \mathrm{min}$, although the increase in the flow rate caused a decrease in the yield, presumably because a shorter residence time leads to an incomplete conversion of the substrate.

Next, the reactions were carried out using multiple monolith $\mathbf{B}$ reactors connected in series (Table 2, n = 3 and 5). The use of multiple reactors connected in series often caused a higher pressure drop, which might be an obstacle for practical continuous production. However, the pressure drop was acceptable in this case because of larger pore size of monolith $\mathbf{B}$. Notably, by using three reactors connected in series, the product was obtained in a quantitative yield with a flow rate three times larger than that for a single reactor $(1.2 \mathrm{~mL} / \mathrm{min})$. Therefore, the productivity can be three times higher than that for a single reactor. Similarly, by using five reactors connected in series, the product was obtained in a quantitative yield with a flow rate five times larger than that for a single reactor $(2.0 \mathrm{~mL} / \mathrm{min})$. Therefore, the productivity was five times larger than that for a single reactor. The increase in the flow rate caused a decrease in the yield because of an incomplete conversion.

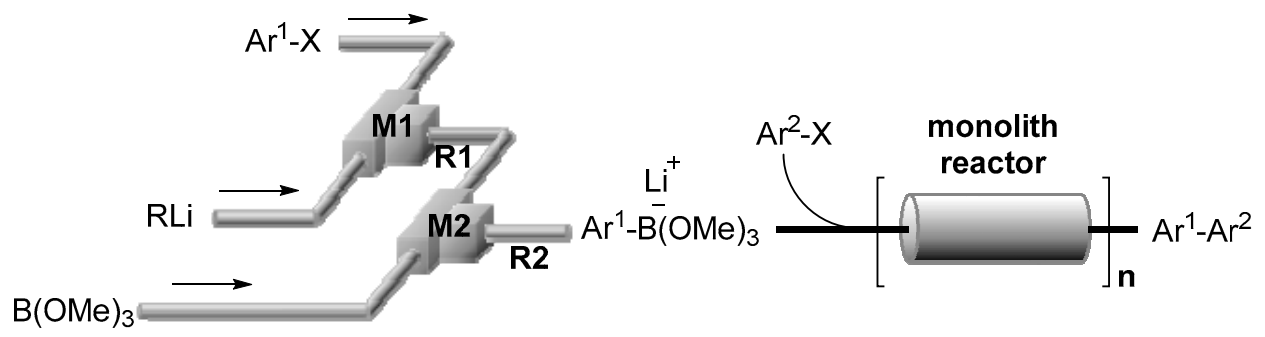

Figure 9. The flow microreactor system for Suzuki-Miyaura coupling using a single reactor or multiple reactors connected in series (micromixers: $\mathbf{M} 1$ and $\mathbf{M} 2$, microtube reactors: $\mathbf{R} \mathbf{1}$ and $\mathbf{R} 2$ ).

Table 2. The effect of the flow rate for the cross-coupling of bromobenzene and $p$-iodobenzonitrile using a single monolith reactor and multiple monolith reactors connected in series.

\begin{tabular}{ccccccc}
\hline Reactor & $\begin{array}{c}\text { n (Number } \\
\text { of Reactors) }\end{array}$ & $\begin{array}{c}\text { Flow Rate } \\
(\mathbf{m L} / \mathbf{m i n})\end{array}$ & $\begin{array}{c}\text { Residence Time } \\
\text { (min) }\end{array}$ & $\begin{array}{c}\text { Pressure Drop } \\
\text { (MPa) }\end{array}$ & $\begin{array}{c}\text { Yield } \\
\text { (\%) }\end{array}$ & $\begin{array}{c}\text { Productivity } \\
\text { (mg/h) }\end{array}$ \\
\hline A & 1 & 0.2 & 9.4 & 0.9 & 96 & 52 \\
A & 1 & 0.4 & 4.7 & 1.7 & 96 & 100 \\
A & 1 & 1.0 & 1.9 & 3.9 & 81 & 220 \\
A & 1 & 1.5 & 1.3 & 5.9 & 66 & 270 \\
B & 1 & 0.2 & 9.6 & 0.3 & 98 & 53 \\
B & 1 & 0.4 & 4.8 & 0.4 & 100 & 110 \\
B & 1 & 1.0 & 1.9 & 0.7 & 87 & 230 \\
B & 1 & 1.5 & 1.3 & 0.9 & 67 & 270 \\
B & 3 & 0.6 & 9.6 & 1.4 & 98 & 160 \\
B & 3 & 1.2 & 4.8 & 3.0 & 97 & 310 \\
B & 3 & 3.0 & 1.9 & 6.8 & 86 & 690 \\
B & 3 & 4.5 & 1.3 & 9.0 & 55 & 670 \\
B & 5 & 1.0 & 9.6 & 3.3 & 100 & 270 \\
B & 5 & 2.0 & 4.8 & 6.6 & 99 & 530 \\
B & 5 & 5.0 & 1.9 & 14 & 75 & 1000 \\
B & 5 & 7.5 & 1.3 & 19 & 52 & 1000 \\
\hline
\end{tabular}

The series connection method is also effective in performing reactions which require longer reaction times. For example, the yields of the reactions with iodobenzene and 1-iodo-4-methoxybenzene as an electron-donating coupling partner could be increased by the series connection of three monolith $\mathbf{B}$ reactors (Table 3). Other examples are also shown in Table 3. 
Table 3. The cross-coupling of $\mathrm{Ar}^{1}-\mathrm{X}$ and $\mathrm{Ar}^{2}-\mathrm{X}$ using a single monolith $\mathbf{B}$ reactor or multiple monolith $\mathbf{B}$ reactors connected in series.

\begin{tabular}{|c|c|c|c|c|c|c|}
\hline \multirow{2}{*}{$A r^{1}-X$} & \multicolumn{2}{|c|}{$\begin{array}{c}\text { Conditions of } \\
\text { Lithiation and Borylation }\end{array}$} & \multirow{2}{*}{$A r^{2}-X$} & \multirow{2}{*}{ Product } & \multicolumn{2}{|c|}{ Yield (\%) ${ }^{a}$} \\
\hline & $\begin{array}{l}t^{\mathrm{R} 1} \\
(\mathrm{~s})\end{array}$ & $\begin{array}{c}\text { Temperature } \\
\left({ }^{\circ} \mathrm{C}\right)\end{array}$ & & & $\mathrm{n}=1$ & $\mathrm{n}=3$ \\
\hline$-\mathrm{Br}$ & 1.7 & 0 & & & 62 & 87 \\
\hline & 1.7 & 0 & & & 41 & 74 \\
\hline$=\int_{\mathrm{CN}}^{\mathrm{Br}}$ & 0.059 & 24 & & & 26 & 65 \\
\hline & 0.059 & 24 & & & 63 & 94 \\
\hline & 0.059 & 24 & & & 43 & 82 \\
\hline
\end{tabular}

${ }^{a}$ Determined by GC.

Moreover, the present method was successfully applied to a gram-scale synthesis of adapalene, which has been used for the treatment of acne, psoriasis, and photoaging (Figure 10). When the coupling of lithium (3-(1-adamantyl)-4-methoxyphenyl)trimethoxyborate and methyl 6-iodo-2-naphthoate was carried out using a single polymer monolith A reactor, a gram scale synthesis was achieved by a $21 \mathrm{~h}$ operation ( $1.55 \mathrm{~g}, 86 \%$ yield). In contrast, by using five monolith $\mathbf{B}$ reactors connected in series, a gram scale synthesis was achieved by a $4 \mathrm{~h}$ operation ( $1.49 \mathrm{~g}, 87 \%$ yield). The productivity increased by five times. The hydrolysis of the coupling product with $\mathrm{NaOH}$ in 1,2-propanediol gave adapalene in an $89 \%$ yield.

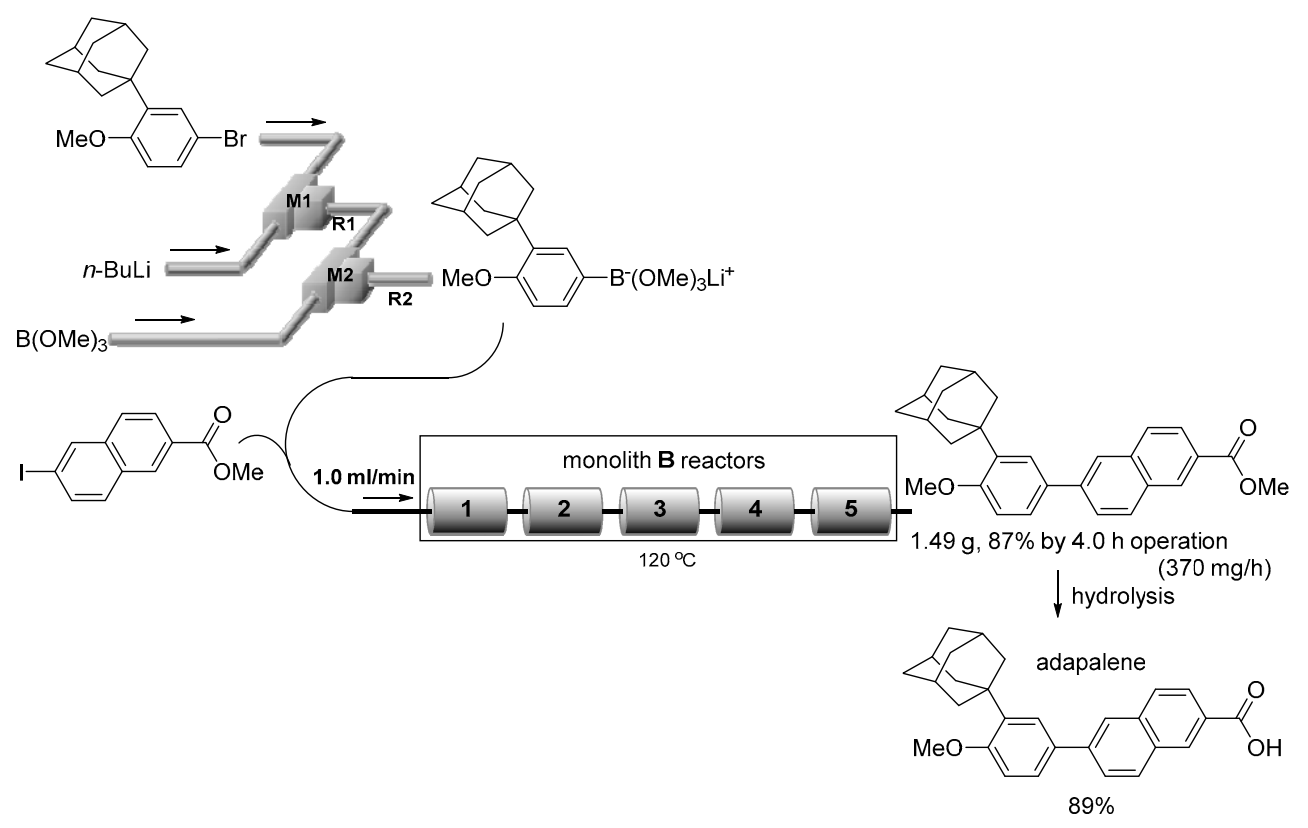

Figure 10. The gram scale synthesis of adapalene. 


\subsection{Recyclability of Monolithic Pd Catalysts}

The leaching of a catalyst into the reaction stream causing the loss of activity due to the decrease in the catalyst loading is one of the potential problems of flow synthesis using supported catalysts. This is particularly problematic for pharmaceutical production. Thus, there is a great demand for developing robustly supported catalysts. To evaluate the recyclability of the catalyst, the reaction followed by washing with THF was repeated fifteen times, and no significant loss of activity was observed based on the yields of the product as shown in Table 4, indicating that the Pd catalysts supported by the polymer monoliths A and B possess a sufficient stability under the reaction conditions. Therefore, these results mean that Pd leaching would not occur under the present experimental conditions.

Table 4. The recyclability of the polymer monolith A and monolith B containing an immobilized Pd catalyst.

\begin{tabular}{ccc}
\hline \multirow{2}{*}{ Cycle Number } & \multicolumn{2}{c}{ Yield (\%) $^{\mathbf{a}}$} \\
\cline { 2 - 3 } & Monolith A & Monolith B \\
\hline 1 & 97 & 97 \\
2 & 96 & 100 \\
3 & 96 & 96 \\
4 & 100 & 97 \\
5 & 97 & 100 \\
6 & 94 & 97 \\
7 & 93 & 93 \\
8 & 95 & 96 \\
9 & 98 & 96 \\
10 & 99 & 99 \\
11 & 99 & 98 \\
12 & 99 & 99 \\
13 & 97 & 99 \\
14 & 99 & 99 \\
15 & 95 & 98 \\
\hline
\end{tabular}

${ }^{\text {a }}$ Determined by GC.

\section{Materials and Methods}

\subsection{General}

A GC analysis was performed on a SHIMADZU GC-2014 gas chromatograph equipped with a flame ionization detector using a fused silica capillary column (column, CBPI; $0.25 \mathrm{~mm} \times 25 \mathrm{~m}$; initial oven temperature, $50{ }^{\circ} \mathrm{C}$; rate of temperature increase, $10{ }^{\circ} \mathrm{C} / \mathrm{min}$; final oven temperature, $\left.250{ }^{\circ} \mathrm{C}\right) .{ }^{1} \mathrm{H}$ and ${ }^{13} \mathrm{C}$ NMR spectra were recorded on a Varian MERCURYplus-400 $\left({ }^{1} \mathrm{H} 400 \mathrm{MHz}\right.$, ${ }^{13} \mathrm{C} 100 \mathrm{MHz}$, Palo Alto, CA, USA) spectrometer with $\mathrm{Me}_{4} \mathrm{Si}$ or $\mathrm{CDCl}_{3}$ as a standard in $\mathrm{CDCl}_{3}$ unless otherwise noted (see Supplementary Materials). A preparative gel permeation chromatography was performed on a Japan Analytical Industry LC-918 (Tokyo, Japan). THF was purchased from Kanto Chemical Co., Inc. (Tokyo, Japan) as a dry solvent and used without further purification. Hexane was purchased from Wako (Kyoto, Japan), distilled before use, and stored over molecular sieves $4 \mathrm{~A}$. Bromobenzene, $p$-bromobenzonitrile, $m$-bromobenzonitrile, $o$-bromobenzonitrile, 4,4'-dibromobiphenyl, 2-bromothiophene, 2-(1-adamantyl)-4-bromoanisole, $p$-iodobenzonitrile, $m$-iodobenzonitrile, $o$-iodobenzonitrile, iodobenzene, methyl 4-iodobenzoate, methyl 2-iodobenzoate, 4-iodoanisole, 2-iodothiophene, 4-iodobenzaldehyde, n-butyllithium phenyllithium, and trimethoxyborane were commercially available. Methyl 6-iodo-2-naphthoate was synthesized according to the literature [136].

Stainless-steel (SUS304) T-shaped micromixers with inner diameters of 250 and $500 \mu \mathrm{m}$ were manufactured by Sanko Seiki Co., Inc. (Tokyo, Japan). Stainless-steel (SUS316) microtube reactors with inner diameters of 500 and $1000 \mu \mathrm{m}$ were purchased from GL Sciences (Tokyo, Japan) and were cut 
into appropriate lengths $(3.5,25,50,100$, and $300 \mathrm{~cm})$. The micromixers and microtube reactors were connected with stainless steel fittings (GL Sciences, $1 / 16$ OUW) to construct the flow microreactor systems. The flow microreactor system was dipped in the bath to control the temperature. The solutions were continuously introduced to the flow microreactor system using syringe pumps, Harvard PHD 2000, equipped with gastight syringes purchased from SGE or a plunger pump, shimadzu LC-20AT (Tokyo, Japan).

\subsection{Preparation of the Pd Catalysts Supported by Monolith $\boldsymbol{A}$ and Monolith $\boldsymbol{B}$}

1,3-Bis( $N, N$-diglycidylaminomethyl)cyclohexane was added to a solution of poly(ethylene glycol) $($ PEG, molecular mass $=200)$ with 4,4'-diaminodicyclohexylmethane and 6-(phenylamino)1,3,5-triazine-2,4-dithiol, and the mixture was stirred at room temperature for $30 \mathrm{~min}$. The resultant homogeneous solution was poured into a cylindrical stainless-steel reactor (an empty HPLC column, $4.6 \mathrm{~mm} \mathrm{ID} \times 150 \mathrm{~mm}$ length). The reactor was annealed to the procedure, epoxy monolithic gels inside. Monolith A was produced by annealing at $100{ }^{\circ} \mathrm{C}$, whereas monolith $\mathbf{B}$ was produced by annealing at $85^{\circ} \mathrm{C}$. The gelation occurred within $30 \mathrm{~min}$, and the samples were subsequently aged at the same temperature for a day. The epoxy monoliths were washed with THF by an HPLC pump at $0.1 \mathrm{~mL} / \mathrm{min}$ for an hour and dried under a vacuum. Then, a THF solution of palladium acetate $(0.5 \mathrm{wt} \%, 5 \mathrm{~mL})$ was injected into the monolith reactor at $0.05 \mathrm{~mL} / \mathrm{min}$. The monolith reactor adsorbed with palladium acetate was immersed in PEG (molecular mass $=300$ ), heat-treated at $100{ }^{\circ} \mathrm{C}$ for $4 \mathrm{~h}$, and was allowed to stand still for overnight at room temperature. THF in the reactor was replaced by PEG300, and the reactor was heat-treated at $200{ }^{\circ} \mathrm{C}$ for $4 \mathrm{~h}$ and was washed with THF $(1 \mathrm{~h})$ and water $(1 \mathrm{~h})$ using an HPLC pump at $0.1 \mathrm{~mL} / \mathrm{min}$. An aqueous solution of sodium borohydride $(0.5 \mathrm{wt} \%, 5 \mathrm{~mL})$ was injected into the reactor at $0.05 \mathrm{~mL} / \mathrm{min}$ to reduce palladium ions adsorbed on the surface of the monolith. Then, the reactor was washed with methanol.

3.3. Cross-Coupling of Bromobenzene and p-Iodobenzonitrile by the Space Integation of Lithiation, Borylation, and Suzuki-Miyaura Coupling

A flow microreactor system consisting of two T-shaped micromixers (M1 and M2), two microtube reactors (R1 and R2), and three tube precooling units (P1 (inner diameter $\phi=1000 \mu \mathrm{m}$, length $\mathrm{L}=100 \mathrm{~cm}), \mathbf{P} 2(\phi=1000 \mu \mathrm{m}, \mathrm{L}=50 \mathrm{~cm})$, and $\mathbf{P 3}(\phi=1000 \mu \mathrm{m}, \mathrm{L}=100 \mathrm{~cm}))$ was used for the formation of lithium borate. A solution of bromobenzene ( $0.10 \mathrm{M}$ in THF) (flow rate: $6.0 \mathrm{~mL} / \mathrm{min}$ ) and a solution of $n$-BuLi $\left(0.60 \mathrm{M}\right.$ in hexane) (flow rate: $1.0 \mathrm{~mL} / \mathrm{min}$ ) were introduced to $\mathbf{M 1}(\phi=500 \mu \mathrm{m})$ at $0{ }^{\circ} \mathrm{C}$ by syringe pumps. The resulting solution was passed through $\mathbf{R} 1\left(\phi=1000 \mu \mathrm{m}, \mathrm{L}=25 \mathrm{~cm}\left(t^{\mathrm{R} 1}=1.7 \mathrm{~s}\right)\right)$ and was mixed with a solution of trimethoxyborane $(0.12 \mathrm{M}$ in THF) (flow rate: $5.0 \mathrm{~mL} / \mathrm{min}$ ) in $\mathbf{M 2}$ $(\phi=500 \mu \mathrm{m})\left(0^{\circ} \mathrm{C}\right)$. The resulting solution was passed through $\mathbf{R} 2\left(\phi=1000 \mu \mathrm{m}, \mathrm{L}=50 \mathrm{~cm}\left(t^{\mathrm{R} 2}=\right.\right.$ $2.0 \mathrm{~s}))\left(0^{\circ} \mathrm{C}\right)$. The resulting solution was collected in a vessel. Then, a solution of $p$-iodobenzonitrile $(0.033 \mathrm{M}$ in $\mathrm{MeOH}(0.67 \mathrm{eq}))$ was added, and the resulting solution was passed through a flow reactor packed with a Pd catalyst supported by monolith $\mathbf{A}$ or monolith $\mathbf{B}$ at $T^{\circ} \mathrm{C}$ by using a plunger pump. The reaction was carried out with various residence times $\left(t^{R}\right)$ by changing the flow rates at various temperatures $(T)$. After a steady state was reached, the product solution was collected (10 min). The reaction mixture was analyzed by GC, and the results are summarized in Tables 5 and 6. 
Table 5. The cross-coupling of bromobenzene and $p$-iodobenzonitrile by the sequence of lithiation, borylation, and Suzuki-Miyaura coupling in a flow (monolith A reactor).

\begin{tabular}{cccc}
\hline $\begin{array}{c}\boldsymbol{T} \\
\left({ }^{\circ} \mathbf{C}\right)\end{array}$ & $\begin{array}{c}\text { Flow Rate } \\
(\mathbf{m L} / \mathbf{m i n})\end{array}$ & $\begin{array}{c}t^{\mathbf{R}} \\
(\mathbf{m i n})\end{array}$ & $\begin{array}{c}\text { Yield } \\
\mathbf{( \% )}\end{array}$ \\
\hline 60 & 0.2 & 9.4 & 37 \\
& 0.4 & 4.7 & 14 \\
& 1.0 & 1.9 & 0 \\
& 1.5 & 1.3 & 0 \\
\hline 80 & 0.2 & 9.4 & 81 \\
& 0.4 & 4.7 & 81 \\
& 1.0 & 1.9 & 39 \\
& 1.5 & 1.3 & 30 \\
\hline 100 & 0.2 & 9.4 & 96 \\
& 0.4 & 4.7 & 96 \\
& 1.0 & 1.9 & 81 \\
& 1.5 & 1.3 & 66 \\
\hline 120 & 0.2 & 9.4 & 100 \\
& 0.4 & 4.7 & 95 \\
& 1.0 & 1.9 & 93 \\
& 1.5 & 1.3 & 96 \\
\hline
\end{tabular}

Table 6. The cross-coupling of bromobenzene and $p$-iodobenzonitrile by the sequence of lithiation, borylation, and Suzuki-Miyaura coupling in a flow (monolith B reactor).

\begin{tabular}{cccc}
\hline $\begin{array}{c}\boldsymbol{T} \\
\left({ }^{\circ} \mathbf{C}\right)\end{array}$ & $\begin{array}{c}\text { Flow Rate } \\
(\mathbf{m L} / \mathbf{m i n})\end{array}$ & $\begin{array}{c}\boldsymbol{t}^{\mathbf{R}} \\
(\mathbf{m i n})\end{array}$ & $\begin{array}{c}\text { Yield } \\
\mathbf{( \% )}\end{array}$ \\
\hline 60 & 0.2 & 9.6 & 50 \\
& 0.4 & 4.8 & 60 \\
& 1.0 & 1.9 & 76 \\
& 1.5 & 1.3 & 82 \\
80 & 0.2 & 9.6 & 61 \\
& 0.4 & 4.8 & 74 \\
& 1.0 & 1.9 & 92 \\
100 & 1.5 & 1.3 & 100 \\
& 0.2 & 9.6 & 67 \\
& 0.4 & 4.8 & 87 \\
& 1.0 & 1.9 & 100 \\
120 & 1.5 & 1.3 & 98 \\
& 0.2 & 9.6 & 89 \\
& 0.4 & 4.8 & 92 \\
& 1.0 & 1.9 & 99 \\
& 1.5 & 1.3 & 99 \\
\hline
\end{tabular}

\section{Biphenyl-4-Carbonitrile}

Synthesized in $52-100 \%$ yield (GC yield using an internal standard (tetradecane)); GC ${ }^{t} R 21.4$ min; ${ }^{1} \mathrm{H}$ NMR $\left(400 \mathrm{MHz}, \mathrm{CDCl}_{3}\right)$ 8 7.76-7.66 (m, 4H), 7.61-7.57 (m, 2H), and 7.52-7.39 (m, 3H). The spectral data were identical to those reported in the literature [137].

3.4. Cross-Coupling of Aryl Bromides $\left(A r^{1}-B r\right)$ and Aryl Halides $\left(A r^{2}-X\right)$ by the Integration of Lithiation, Borylation and Suzuki-Miyaura Coupling in a Flow (Monolith A Reactor)

A flow microreactor system consisting of two T-shaped micromixers (M1 and M2), two microtube reactors (R1 and R2), and three tube precooling units (P1 (inner diameter $\phi=1000 \mu \mathrm{m}$, length $\mathrm{L}=100 \mathrm{~cm}), \mathbf{P} 2(\phi=1000 \mu \mathrm{m}, \mathrm{L}=50 \mathrm{~cm})$, and $\mathbf{P 3}(\phi=1000 \mu \mathrm{m}, \mathrm{L}=100 \mathrm{~cm}))$ was used for the formation of lithium borate. A solution of arylbromides $\left(\mathrm{Ar}^{1}-\mathrm{Br}\right)(0.10 \mathrm{M}$ in THF) (flow rate: $6.0 \mathrm{~mL} / \mathrm{min})$ and a 
solution of $n$-BuLi $(0.60 \mathrm{M}$ in hexane) (flow rate: $1.0 \mathrm{~mL} / \mathrm{min})$ were introduced to $\mathbf{M 1}(\phi=250 \mu \mathrm{m})$ by syringe pumps. The resulting solution was passed through R1 $(1.7 \mathrm{~s}(\phi=1000 \mu \mathrm{m}, \mathrm{L}=25 \mathrm{~cm})$ or $0.059 \mathrm{~s}$ $(\phi=500 \mu \mathrm{m}, \mathrm{L}=3.5 \mathrm{~cm}))$ and was mixed with a solution of trimethoxyborane ( $0.12 \mathrm{M}$ in THF) (flow rate: $5.0 \mathrm{~mL} / \mathrm{min})$ in $\mathbf{M} 2(\phi=250 \mu \mathrm{m})$. The resulting solution was passed through $\mathbf{R} \mathbf{2}(\phi=1000 \mu \mathrm{m}$, $\left.\mathrm{L}=50 \mathrm{~cm}\left(t^{\mathrm{R} 2}=2.0 \mathrm{~s}\right)\right)\left(\right.$ for the case of $2,2^{\prime}$-dibromobiphenyl, $\mathbf{R} 2\left(\phi=1000 \mu \mathrm{m}, \mathrm{L}=300 \mathrm{~cm}\left(t^{\mathrm{R} 2}=11.8 \mathrm{~s}\right)\right)$ was used). The resulting solution was collected in a vessel. Then, a solution of arylhalides $\left(\mathrm{Ar}^{2}-\mathrm{X}\right)$ $(0.033 \mathrm{M}$ in $\mathrm{MeOH}(0.67 \mathrm{eq}))$ was added, and the resulting solution was passed through a flow reactor packed with a polymer monolith A containing immobilized Pd by a plunger pump (condition (a): $t^{\mathrm{R}}=4.7 \mathrm{~min}, T=100^{\circ} \mathrm{C}$ or condition (b): $t^{\mathrm{R}}=9.4 \mathrm{~min}, T=120^{\circ} \mathrm{C}$ ). After a steady state was reached, the product solution was collected (10 $\mathrm{min}$ ) (for the case of 2,2'-dibromobiphenyl, $100 \mathrm{~min}$ ). The yield of product was determined by GC analysis or isolation. The results are summarized in Table 1.

\section{Methyl 4-Phenylbenzoate}

Synthesized in 76\% yield (condition (a)) or $87 \%$ (condition (b)) (GC yield using an internal standard (tetradecane)); GC ${ }^{t} R 22.9 \mathrm{~min} ;{ }^{1} \mathrm{H}$ NMR $\left(400 \mathrm{MHz}, \mathrm{CDCl}_{3}\right) \delta 8.13-8.08(\mathrm{~m}, 2 \mathrm{H}), 7.69-7.60$ (m, $4 \mathrm{H}), 7.50-7.36(\mathrm{~m}, 3 \mathrm{H})$, and $3.94(\mathrm{~s}, 3 \mathrm{H})$. The spectral data were identical to those reported in the literature [138].

\section{Biphenyl}

Synthesized in $6 \%$ yield (condition (a)) or $41 \%$ (condition (b)) (GC yield using an internal standard (tetradecane)); GC ${ }^{t} R 17.0 \mathrm{~min} ;{ }^{1} \mathrm{H}$ NMR $\left(400 \mathrm{MHz}, \mathrm{CDCl}_{3}\right) \delta$ 7.62-7.57 (m, 4H), 7.47-7.41 (m, 4H), and 7.38-7.32 $(\mathrm{m}, 2 \mathrm{H})$. The spectral data were identical to those reported in the literature [139].

\section{4-Methoxybiphenyl}

Synthesized in 1\% yield (condition (a)) or 29\% (condition(b)) (GC yield using an internal standard (tetradecane)); GC ${ }^{t} R 20.7 \mathrm{~min} ;{ }^{1} \mathrm{H}$ NMR $\left(400 \mathrm{MHz}, \mathrm{CDCl}_{3}\right) \delta$ 7.58-7.50 (m, 4H), 7.45-7.37 (m, 2H), 7.30 $(\mathrm{t}, J=8.0 \mathrm{~Hz}, 1 \mathrm{H}), 6.98(\mathrm{~d}, J=8.8 \mathrm{~Hz}, 2 \mathrm{H})$, and $3.85(\mathrm{~s}, 3 \mathrm{H})$. The spectral data were identical to those reported in the literature [140].

\section{2-Phenylthiophene}

Synthesized in $86 \%$ yield (condition (a)) or $92 \%$ (condition (b)) (GC yield using an internal standard (pentadecane)); $\mathrm{GC}^{t} \mathrm{R} 25.6 \mathrm{~min} ;{ }^{1} \mathrm{H}$ NMR $\left(400 \mathrm{MHz}, \mathrm{CDCl}_{3}\right) \delta 7.64-7.58(\mathrm{~m}, 2 \mathrm{H}), 7.41-7.35(\mathrm{~m}, 2 \mathrm{H})$, $7.33-7.26(\mathrm{~m}, 3 \mathrm{H})$, and $7.08(\mathrm{dd}, J=3.6 \mathrm{~Hz}, J=4.8 \mathrm{~Hz}, 1 \mathrm{H})$. The spectral data were identical to those reported in the literature [141].

\section{4,4'-Dicyanobiphenyl}

Synthesized in $68 \%$ yield (condition (a)) or 91\% (condition (b)) (GC yield using an internal standard (tetradecane)); $\mathrm{GC}^{t} R 25.4 \mathrm{~min} ;{ }^{1} \mathrm{H}$ NMR $\left(400 \mathrm{MHz}, \mathrm{CDCl}_{3}\right) \delta$ 7.81-7.76 $(\mathrm{m}, 4 \mathrm{H})$, and 7.72-7.67 (m, 4H). The spectral data were identical to those reported in the literature [142].

\section{3,4'-Dicyanobiphenyl}

Synthesized in $17 \%$ yield under condition (a) or $83 \%$ under condition (b) (GC yield using an internal standard (tetradecane)); $\mathrm{GC}^{t} \mathrm{R} 25.2 \mathrm{~min} ;{ }^{1} \mathrm{H}$ NMR $\left(400 \mathrm{MHz}, \mathrm{CDCl}_{3}\right) \delta 7.87(\mathrm{~s}, 1 \mathrm{H}), 7.84-7.75(\mathrm{~m}, 3 \mathrm{H})$, $7.72(\mathrm{~d}, J=7.6 \mathrm{~Hz}, 1 \mathrm{H}), 7.67(\mathrm{~d}, J=8.0 \mathrm{~Hz}, 2 \mathrm{H})$, and $7.61(\mathrm{t}, J=7.6 \mathrm{~Hz}, 1 \mathrm{H}) ;{ }^{13} \mathrm{C} \mathrm{NMR}\left(100 \mathrm{MHz}, \mathrm{CDCl}_{3}\right)$ $\delta$ 143.2, 140.4, 132.9, 132.0, 131.5, 130.8, 130.0, 127.8, 118.4, 118.3, 113.5, and 112.2; HRMS (ACPI) calcd. for $\mathrm{C}_{14} \mathrm{H}_{9} \mathrm{~N}_{2}{ }^{+}[\mathrm{MH}+]$ : 205.0760, found: 205.0759.

\section{2, $\mathbf{4}^{\prime}$-Dicyanobiphenyl}

Synthesized in $12 \%$ yield (condition (a)) or $91 \%$ (condition (b)) (GC yield using an internal standard (tetradecane)); $\mathrm{GC}^{t} \mathrm{R} 24.2 \mathrm{~min} ;{ }^{1} \mathrm{H} \mathrm{NMR}\left(400 \mathrm{MHz}, \mathrm{CDCl}_{3}\right) \delta 7.84-7.78(\mathrm{~m}, 3 \mathrm{H}), 7.74-7.65(\mathrm{~m}, 3 \mathrm{H})$, and 
7.57-7.50 (m, 2H); ${ }^{13} \mathrm{C}$ NMR (100 MHz, $\left.\mathrm{CDCl}_{3}\right) \delta 143.3,142.5,134.0,133.2,132.5,129.9,129.6,128.8$, 118.4, 118.0, 112.7, and 111.2; HRMS (ACPI) calcd. for $\mathrm{C}_{14} \mathrm{H}_{9} \mathrm{~N}_{2}+[\mathrm{MH}+]$ : 205.0760, found: 205.0758.

\section{Methyl 4-(4-Cyanophenyl)benzoate}

Synthesized in $34 \%$ yield (condition (a)) or $84 \%$ (condition (b)) (GC yield using an internal standard (tetradecane)); GC ${ }^{t} R 26.5 \mathrm{~min} ;{ }^{1} \mathrm{H}$ NMR $\left(400 \mathrm{MHz}, \mathrm{CDCl}_{3}\right) \delta 8.17-8.12(\mathrm{~m}, 2 \mathrm{H}), 7.78-7.69(\mathrm{~m}$, $4 \mathrm{H}), 7.68-7.64(\mathrm{~m}, 2 \mathrm{H})$, and $3.96(\mathrm{~s}, 3 \mathrm{H})$. The spectral data were identical to those reported in the literature [143].

\section{Methyl 4-(3-Cyanophenyl)benzoate}

Synthesized in 15\% yield (condition (a)) or 87\% (condition (b)) (GC yield using an internal standard (tetradecane)); GC ${ }^{t} R 26.3 \mathrm{~min} ;{ }^{1} \mathrm{H}$ NMR $\left(400 \mathrm{MHz}, \mathrm{CDCl}_{3}\right) \delta 8.14(\mathrm{~d}, J=8.0 \mathrm{~Hz}, 2 \mathrm{H}), 7.90(\mathrm{~s}, 1 \mathrm{H})$, $7.84(\mathrm{~d}, J=7.6 \mathrm{~Hz}, 1 \mathrm{H}), 7.68(\mathrm{~d}, J=7.6 \mathrm{~Hz}, 1 \mathrm{H}), 7.63(\mathrm{~d}, J=8.0 \mathrm{~Hz}, 2 \mathrm{H}), 7.58(\mathrm{t}, J=7.6 \mathrm{~Hz}, 1 \mathrm{H})$, and $3.95(\mathrm{~s}, 3 \mathrm{H}) ;{ }^{13} \mathrm{C} \mathrm{NMR}\left(100 \mathrm{MHz}, \mathrm{CDCl}_{3}\right) \delta 166.6,143.1,141.3,131.6,131.5,130.8,130.4,130.0,129.8$, 127.1, 118.6, 113.2, and 52.3; HRMS (ACPI) calcd. for $\mathrm{C}_{15} \mathrm{H}_{11} \mathrm{NO}_{2}$ [M+]: 237.0784, found: 237.0789. The spectral data were identical to those reported in the literature [105].

\section{Methyl 4-(2-Cyanophenyl)benzoate}

Synthesized in $2 \%$ yield (condition (a)) or 52\% (condition (b)) (GC yield using an internal standard (tetradecane)); GC ${ }^{t} R 25.6 \mathrm{~min} ;{ }^{1} \mathrm{H}$ NMR $\left(400 \mathrm{MHz}, \mathrm{CDCl}_{3}\right) \delta 8.19-8.14(\mathrm{~m}, 2 \mathrm{H}), 7.82-7.78(\mathrm{~m}, 1 \mathrm{H})$, $7.71-7.61(\mathrm{~m}, 3 \mathrm{H}), 7.56-7.46(\mathrm{~m}, 2 \mathrm{H})$, and $3.96(\mathrm{~s}, 3 \mathrm{H})$. The spectral data were identical to those of reported in the literature [144].

\section{1-Cyano-4"-bromo-4,1':4',1"-terphenylene}

Synthesized in 54\% yield (condition (b)) (isolated yield). After the extraction with EtOAc, the crude product was thoroughly washed with hexane and water to give the product as a white solid (59.8 $\mathrm{mg})$; ${ }^{1} \mathrm{H}$ NMR $\left(400 \mathrm{MHz}, \mathrm{CDCl}_{3}\right) \delta 7.77-7.70(\mathrm{~m}, 4 \mathrm{H}), 7.68(\mathrm{~s}, 4 \mathrm{H}), 7.60(\mathrm{~d}, J=8.8 \mathrm{~Hz}, 2 \mathrm{H})$, and $7.51(\mathrm{~d}$, $J=8.8 \mathrm{~Hz}, 2 \mathrm{H})$. The spectral data were identical to those reported in the literature [145].

\section{2,2'-Bithiophene}

Synthesized in $83 \%$ yield (condition (a)) or $94 \%$ (condition (b)) (GC yield using an internal standard (pentadecane)); GC ${ }^{t} R 25.6 \mathrm{~min} ;{ }^{1} \mathrm{H}$ NMR $\left(400 \mathrm{MHz}, \mathrm{CDCl}_{3}\right) \delta 7.21(\mathrm{dd}, J=1.2 \mathrm{~Hz}, J=5.2 \mathrm{~Hz}, 1 \mathrm{H})$, $7.17(\mathrm{dd}, J=1.2 \mathrm{~Hz}, J=3.6 \mathrm{~Hz}, 1 \mathrm{H})$, and $7.01(\mathrm{dd}, J=3.6 \mathrm{~Hz}, J=5.2 \mathrm{~Hz}, 1 \mathrm{H})$. The spectral data were identical to those reported in the literature [146].

\section{4-(Thiophen-2-yl)benzonitrile}

Synthesized in 78\% yield (condition (a)) or 87\% (condition (b)) (GC yield using an internal standard (tetradecane)); GC ${ }^{t} R 25.6 \mathrm{~min} ;{ }^{1} \mathrm{H}$ NMR $\left(400 \mathrm{MHz}, \mathrm{CDCl}_{3}\right) \delta 7.72-7.63(\mathrm{~m}, 4 \mathrm{H}), 7.44-7.38(\mathrm{~m}, 2 \mathrm{H})$, and $7.13(\mathrm{dd}, J=3.6 \mathrm{~Hz}, J=5.2 \mathrm{~Hz}, 1 \mathrm{H})$. The spectral data were identical to those reported in the literature [147].

\section{Methyl 4-(Thiophen-2-yl)benzoate}

Synthesized in 71\% yield (condition (a)) or $86 \%$ (condition (b)) (GC yield using an internal standard (tetradecane)); GC ${ }^{t} R 25.6 \mathrm{~min} ;{ }^{1} \mathrm{H}$ NMR $\left(400 \mathrm{MHz}, \mathrm{CDCl}_{3}\right) \delta 8.07-8.02(\mathrm{~m}, 2 \mathrm{H}), 7.70-7.65(\mathrm{~m}, 1 \mathrm{H}), 7.42$ $(\mathrm{dd}, J=1.2 \mathrm{~Hz}, J=3.6 \mathrm{~Hz}, 1 \mathrm{H}), 7.36(\mathrm{dd}, J=1.2 \mathrm{~Hz}, J=5.2 \mathrm{~Hz}, 1 \mathrm{H}), 7.11(\mathrm{dd}, J=3.6 \mathrm{~Hz}, J=5.2 \mathrm{~Hz}, 1 \mathrm{H})$, and $3.93(\mathrm{~s}, 3 \mathrm{H})$; The spectral data were identical to those reported in the literature [148]. 
3.5. Cross-Coupling of Aryl Bromides $\left(A r^{1}-B r\right)$ and Aryl Halides $\left(A r^{2}-X\right)$ by the Integration of Lithiation, Borylation, and Suzuki-Miyaura Coupling Using a Single Monolith B Reactor or Three Monolith B Reactors Connected in Series

A flow microreactor system consisting of two T-shaped micromixers (M1 and M2), two microtube reactors (R1 and R2), and three tube precooling units (P1 (inner diameter $\phi=1000 \mu \mathrm{m}$, length $\mathrm{L}=100 \mathrm{~cm}), \mathbf{P} 2(\phi=1000 \mu \mathrm{m}, \mathrm{L}=50 \mathrm{~cm})$, and $\mathbf{P 3}(\phi=1000 \mu \mathrm{m}, \mathrm{L}=100 \mathrm{~cm}))$ was used for the formation of lithium borate. A solution of arylbromides $\left(\mathrm{Ar}^{1} \mathrm{Br}\right)(0.10 \mathrm{M}$ in THF) (flow rate: $6.0 \mathrm{~mL} / \mathrm{min})$ and a solution of $n$-BuLi $(0.60 \mathrm{M}$ in hexane) (flow rate: $1.0 \mathrm{~mL} / \mathrm{min})$ were introduced to $\mathbf{M 1}(\phi=250 \mu \mathrm{m})$ by syringe pumps. The resulting solution was passed through R1 $(1.7 \mathrm{~s}(\phi=1000 \mu \mathrm{m}, \mathrm{L}=25 \mathrm{~cm})$ or $0.059 \mathrm{~s}(\phi=500 \mu \mathrm{m}, \mathrm{L}=3.5 \mathrm{~cm}))$ and was mixed with a solution of trimethoxyborane $(0.12 \mathrm{M}$ in THF) (flow rate: $5.0 \mathrm{~mL} / \mathrm{min}$ ) in $\mathbf{M} 2(\phi=250 \mu \mathrm{m})$. The resulting solution was passed through $\mathbf{R} 2$ $\left(\phi=1000 \mu \mathrm{m}, \mathrm{L}=50 \mathrm{~cm}\left(t^{\mathrm{R} 2}=2.0 \mathrm{~s}\right)\right)$. The resulting solution was collected in a vessel. Then, a solution of arylhalides $\left(\mathrm{Ar}^{2} \mathrm{X}\right)(0.033 \mathrm{M}$ in $\mathrm{MeOH}(0.67 \mathrm{eq}))$ was added, and the mixing solution was passed through a single monolith $\mathbf{B}$ reactor $\left(0.10 \mathrm{~mL} / \mathrm{min}(19.2 \mathrm{~min}), 120^{\circ} \mathrm{C}\right)$ or three monolith $\mathbf{B}$ reactors connected in series $\left(0.10 \mathrm{~mL} / \mathrm{min}(57.6 \mathrm{~min}), 120^{\circ} \mathrm{C}\right)$. After a steady state was reached, the product solution was collected (10 min). The yield of the product was determined by GC analysis or isolation. The results are summarized in Table 2.

\section{2-Cyano-4'-formylbiphenyl}

Synthesized in $65 \%$ yield in three monolith $\mathbf{B}$ reactors (GC yield using an internal standard (tetradecane)); GC ${ }^{t} R 24.0 \mathrm{~min} ;{ }^{1} \mathrm{H}$ NMR $\left(400 \mathrm{MHz}, \mathrm{CDCl}_{3}\right) \delta 10.10(\mathrm{~s}, 1 \mathrm{H}), 8.04-8.00(\mathrm{~m}, 2 \mathrm{H}), 7.84-7.80$ $(\mathrm{m}, 1 \mathrm{H}), 7.76-7.67(\mathrm{~m}, 3 \mathrm{H})$, and 7.57-7.50 (m, 2H); ${ }^{13} \mathrm{C} \mathrm{NMR}\left(100 \mathrm{MHz}, \mathrm{CDCl}_{3}\right) \delta 191.7$ 144.0, 143.9, 136.2, 133.9, 133.0, 130.1, 130.0, 129.5, 128.5, 118.2, and 111.3; HRMS (ACPI) calcd. for $\mathrm{C}_{14} \mathrm{H}_{10} \mathrm{NO}^{+}\left[\mathrm{MH}^{+}\right]$: 208.0762, found: 208.0753. The spectral data were identical to those reported in the literature [149].

\section{2,2'-Dicyanobiphenyl}

Synthesized in $63 \%$ yield using one reactor or $94 \%$ yield using three reactors (GC yield using an internal standard (tetradecane)); $\mathrm{GC}^{t} R 22.8 \mathrm{~min} ;{ }^{1} \mathrm{H}$ NMR $\left(400 \mathrm{MHz}, \mathrm{CDCl}_{3}\right) \delta 7.86-7.81(\mathrm{~m}, 2 \mathrm{H}), 7.73$ $(\mathrm{td}, J=7.6 \mathrm{~Hz}, J=1.2 \mathrm{~Hz}, 2 \mathrm{H})$, and $7.62-7.56(\mathrm{~m}, 4 \mathrm{H})$. The spectral data were identical to those reported in the literature [139].

\section{Methyl 2-(2-Cyanophenyl)benzoate}

Synthesized in $43 \%$ yield using one reactor or $82 \%$ yield using three reactors (GC yield using an internal standard (tetradecane)); GC ${ }^{t} R 23.3 \mathrm{~min} ;{ }^{1} \mathrm{H}$ NMR $\left(400 \mathrm{MHz}, \mathrm{CDCl}_{3}\right) \delta 8.12-8.07(\mathrm{~m}, 1 \mathrm{H})$, 7.74-7.70 (m, 1H), 7.65-7.59 (m, 2H), 7.56-7.50 (m, 1H), $7.46(\mathrm{td}, J=7.6 \mathrm{~Hz}, J=1.2 \mathrm{~Hz}, 1 \mathrm{H}), 7.37-7.31$ $(\mathrm{m}, 2 \mathrm{H})$, and $3.71(\mathrm{~s}, 3 \mathrm{H}) ;{ }^{13} \mathrm{C} \mathrm{NMR}\left(100 \mathrm{MHz}, \mathrm{CDCl}_{3}\right) \delta 166.9,145.8,139.6,132.3,132.2,132.1131 .0$, 130.8, 129.6, 129.5, 128.8, 127.5, 118.0, 112.3, and 52.1; HRMS (EI) calcd. for $\mathrm{C}_{15} \mathrm{H}_{11} \mathrm{NO}_{2}$ [M+]: 237.0790, found: 237.0788 .

3.6. Cross-Coupling of Bromobenzene and p-Iodobenzonitrile by the Integration of Lithiation, Borylation, and Suzuki-Miyaura Coupling Using Multiple Monolith B Reactors Connected in Series

A flow microreactor system consisting of two T-shaped micromixers (M1 and M2), two microtube reactors (R1 and R2), and three tube precooling units (P1 (inner diameter $\phi=1000 \mu \mathrm{m}$, length $\mathrm{L}=100 \mathrm{~cm}), \mathbf{P} 2(\phi=1000 \mu \mathrm{m}, \mathrm{L}=50 \mathrm{~cm})$, and $\mathbf{P 3}(\phi=1000 \mu \mathrm{m}, \mathrm{L}=100 \mathrm{~cm}))$ was used for the formation of lithium borate. A solution of bromobenzene $(0.10 \mathrm{M}$ in THF) (flow rate: $6.0 \mathrm{~mL} / \mathrm{min}$ ) and a solution of $n$ - BuLi $\left(0.60 \mathrm{M}\right.$ in hexane) (flow rate: $1.0 \mathrm{~mL} / \mathrm{min}$ ) were introduced to $\mathbf{M 1}(\phi=500 \mu \mathrm{m})$ at $0{ }^{\circ} \mathrm{C}$ by syringe pumps. The resulting solution was passed through $\mathbf{R} 1\left(\phi=1000 \mu \mathrm{m}, \mathrm{L}=25 \mathrm{~cm}\left(t^{\mathrm{R} 1}=1.7 \mathrm{~s}\right)\right)$ and was mixed with a solution of trimethoxyborane ( $0.12 \mathrm{M}$ in THF) (flow rate: $5.0 \mathrm{~mL} / \mathrm{min}$ ) in $\mathbf{M 2}$ $(\phi=500 \mu \mathrm{m})\left(0^{\circ} \mathrm{C}\right)$. The resulting solution was passed through $\mathbf{R} 2\left(\phi=1000 \mu \mathrm{m}, \mathrm{L}=50 \mathrm{~cm}\left(t^{\mathrm{R} 2}=2.0 \mathrm{~s}\right)\right)$ $\left(0^{\circ} \mathrm{C}\right)$. The resulting solution was collected in a vessel. Then, a solution of $p$-iodobenzonitrile $(0.033 \mathrm{M}$ 
in $\mathrm{MeOH}(0.67 \mathrm{eq}))$ was added, and the mixing solution was passed through a flow reactor packed with three or five monolith $\mathbf{B}$ reactors connected in series at $100^{\circ} \mathrm{C}$ by a plunger pump. The reaction was carried out for various residence times $\left(t^{\mathrm{R}}\right)$ in the reactor by changing flow rates. After a steady state was reached, the product solution was collected $(10 \mathrm{~min})$. The reaction mixture was analyzed by GC, and the results are summarized in Table 3.

\subsection{Synthesis of Adapalene}

A flow microreactor system consisting of two T-shaped micromixers (M1 and M2), two microtube reactors (R1 and R2), and three tube precooling units (P1 (inner diameter $\phi=1000 \mu \mathrm{m}$, length $\mathrm{L}=100 \mathrm{~cm}), \mathbf{P} 2(\phi=1000 \mu \mathrm{m}, \mathrm{L}=50 \mathrm{~cm})$, and $\mathbf{P} \mathbf{3}(\phi=1000 \mu \mathrm{m}, \mathrm{L}=100 \mathrm{~cm}))$ was used for the formation of lithium borate. A solution of 2-(1-Adamantyl)-4-bromoanisole (0.10 M in THF) (flow rate: $6.0 \mathrm{~mL} / \mathrm{min})$ and a solution of $n-\mathrm{BuLi}(0.60 \mathrm{M}$ in hexane) (flow rate: $1.0 \mathrm{~mL} / \mathrm{min}$ ) were introduced to $\mathbf{M 1}(\phi=500 \mu \mathrm{m})$ at $0^{\circ} \mathrm{C}$ by syringe pumps. The resulting solution was passed through $\mathbf{R} \mathbf{1}(\phi=1000 \mu \mathrm{m}$, $\left.\mathrm{L}=50 \mathrm{~cm}\left(t^{\mathrm{R} 1}=3.4 \mathrm{~s}\right)\right)$ and was mixed with a solution of trimethoxyborane $(0.12 \mathrm{M}$ in THF) (flow rate: $5.0 \mathrm{~mL} / \mathrm{min})$ in $\mathbf{M} 2(\phi=500 \mu \mathrm{m})$. The resulting solution was passed through $\mathbf{R} 2(\phi=1000 \mu \mathrm{m}$, $\left.\mathrm{L}=50 \mathrm{~cm}\left(t^{\mathrm{R} 2}=2.0 \mathrm{~s}\right)\right)$. The resulting solution was collected in a vessel.

Then, a solution of methyl 6-iodo-2-naphthoate (0.033 $\mathrm{M}$ in THF/MeOH $=1.5: 1)$ was added, and the mixing solution was passed through a monolithic reactor at $120^{\circ} \mathrm{C}$ by a plunger pump. The reaction was carried out using a single monolith $\mathbf{A}$ reactor (flow rate: $0.2 \mathrm{~mL} / \mathrm{min}$ ) (residence time: $9.4 \mathrm{~min}$ ) or five monolith $\mathbf{B}$ reactors (flow rate: $1.0 \mathrm{~mL} / \mathrm{min}$ ) (residence time: $9.5 \mathrm{~min}$ ). After a steady state was reached, the product solution was collected in $21 \mathrm{~h}$ (a single monolith A reactor) or $4 \mathrm{~h}$ (five monolith $\mathbf{B}$ reactors). After the evaporation of the solvents, the crude product was thoroughly washed with $\mathrm{MeOH}(2 \times 150 \mathrm{~mL})$ to give methyl 6-(3-(1-adamantyl)-4-methoxyphenyl)-2-naphthoate (1.55 g (one single monolith A reactor), $1.49 \mathrm{~g}$ (five monolith $\mathbf{B}$ reactors)).

Methyl 6-(3-(1-adamantyl)-4-methoxyphenyl)-2-naphthoate $(0.517 \mathrm{~g})$ and $20 \mathrm{~mL}$ of 1,2-propanediol were placed in a flask, and the mixture was heated to $190{ }^{\circ} \mathrm{C}$. The resulting transparent solution was supplemented with $0.534 \mathrm{~g}$ of sodium hydroxide in two portions and mixed for $20 \mathrm{~min}$. The mixture was acidified until $\mathrm{pH} 1$ with $6 \mathrm{~N} \mathrm{HCl}$. The resulting suspension was mixed for $30 \mathrm{~min}$ and washed with hot water $(2 \times 50 \mathrm{~mL})$. After drying for $12 \mathrm{~h}$ at $120^{\circ} \mathrm{C}$, the yield was $0.458 \mathrm{~g}(89 \%)$.

\section{Methyl 6-Iodo-2-naphthoate}

${ }^{1} \mathrm{H}$ NMR $\left(400 \mathrm{MHz}, \mathrm{CDCl}_{3}\right) \delta 8.56(\mathrm{~s}, 1 \mathrm{H}), 8.29(\mathrm{~s}, 1 \mathrm{H}), 8.07(\mathrm{dd}, J=8.6 \mathrm{~Hz}, J=2.0 \mathrm{~Hz}, 1 \mathrm{H}), 7.79(\mathrm{dd}$, $J=8.8 \mathrm{~Hz}, J=2.0 \mathrm{~Hz} 1 \mathrm{H}), 7.76(\mathrm{~d}, J=8.4 \mathrm{~Hz}, 1 \mathrm{H}), 7.67(\mathrm{~d}, J=8.8 \mathrm{~Hz}, 1 \mathrm{H})$, and $3.98(\mathrm{~s}, 3 \mathrm{H}) ;{ }^{13} \mathrm{C} \mathrm{NMR}$ $\left(100 \mathrm{MHz}, \mathrm{CDCl}_{3}\right) \delta 166.9,136.7,136.6,135.3,131.1,130.9,130.6,127.9,127.0,126.2,94.7$, and 52.3; HRMS (ACPI) calcd. for $\mathrm{C}_{12} \mathrm{H}_{10} \mathrm{IO}_{2}\left[\mathrm{MH}^{+}\right]$: 312.9720, found: 312.9711. The spectral data were identical to those reported in the literature [137].

\section{Methyl 6-(3-(1-Adamantyl)-4-methoxyphenyl)-2-naphthoate}

${ }^{1} \mathrm{H}$ NMR $\left(400 \mathrm{MHz}, \mathrm{CDCl}_{3}\right) \delta 8.61(\mathrm{~s}, 1 \mathrm{H}), 8.07(\mathrm{dd}, J=8.6 \mathrm{~Hz}, J=1.6 \mathrm{~Hz}, 1 \mathrm{H}), 8.01(\mathrm{~s}, 1 \mathrm{H}), 7.99(\mathrm{~d}$, $J=8.4 \mathrm{~Hz}, 1 \mathrm{H}), 7.92(\mathrm{~d}, J=8.4 \mathrm{~Hz}, 1 \mathrm{H}), 7.80(\mathrm{dd}, J=8.6 \mathrm{~Hz}, J=2.0 \mathrm{~Hz}, 1 \mathrm{H}), 7.60(\mathrm{~d}, J=2.4 \mathrm{~Hz}, 1 \mathrm{H}), 7.55$ $(\mathrm{dd}, J=8.0 \mathrm{~Hz}, J=2.4 \mathrm{~Hz}, 1 \mathrm{H}), 7.00(\mathrm{~d}, J=8.4 \mathrm{~Hz}, 1 \mathrm{H}), 3.99(\mathrm{~s}, 3 \mathrm{H}), 3.91(\mathrm{~s}, 3 \mathrm{H}), 2.18(\mathrm{~s}, 6 \mathrm{H}), 2.10(\mathrm{~s}$, $3 \mathrm{H})$, and $1.57(\mathrm{~s}, 6 \mathrm{H})$. The spectral data were identical to those of reported in the literature [150].

\section{6-(3-(1-Adamantyl)-4-methoxyphenyl)-2-naphthoic Acid (Adapalene)}

${ }^{1} \mathrm{H}$ NMR $\left(400 \mathrm{MHz}\right.$, DMSO- $\left.d_{6}\right) \delta 13.09$ (brs, $\left.1 \mathrm{H}\right), 8.58(\mathrm{~s}, 1 \mathrm{H}), 8.21(\mathrm{~s}, 1 \mathrm{H}), 8.14(\mathrm{~d}, J=8.8 \mathrm{~Hz}, 1 \mathrm{H}), 8.06$ $(\mathrm{d}, J=9.2 \mathrm{~Hz}, 1 \mathrm{H}), 7.97(\mathrm{dd}, J=8.4 \mathrm{~Hz}, J=1.6 \mathrm{~Hz}, 1 \mathrm{H}), 7.88(\mathrm{dd}, J=8.6 \mathrm{~Hz}, J=1.6 \mathrm{~Hz}, 1 \mathrm{H}), 7.65(\mathrm{dd}$, $J=8.4 \mathrm{~Hz}, J=2.4 \mathrm{~Hz}, 1 \mathrm{H}), 7.57(\mathrm{~d}, J=2.4 \mathrm{~Hz}, 1 \mathrm{H}), 7.11(\mathrm{~d}, J=8.8 \mathrm{~Hz}, 1 \mathrm{H}), 3.86(\mathrm{~s}, 3 \mathrm{H}), 2.13(\mathrm{~s}, 6 \mathrm{H}), 2.06$ $(\mathrm{s}, 3 \mathrm{H})$, and $1.75(\mathrm{~s}, 6 \mathrm{H})$. The spectral data were identical to those reported in the literature [150]. 


\subsection{Recyclability of the Polymer Monolith $\boldsymbol{A}$ and Monolith $\boldsymbol{B}$ Reactors}

The mixing solution of phenyllithium $\left(0.050 \mathrm{M}\right.$ in $\mathrm{Et}_{2} \mathrm{O} / \mathrm{THF}=1: 19$ (1.00 eq)), trimethoxyborane $\left(0.050 \mathrm{M}\right.$ in $\mathrm{Et}_{2} \mathrm{O} / \mathrm{THF}=1: 19$ (1.00 eq)), and $p$-cyanoiodobenzene $(0.033 \mathrm{M}$ in $\mathrm{MeOH}(0.67 \mathrm{eq}))$ was passed through a flow reactor packed with a Pd catalyst supported by monolith A or monolith $\mathbf{B}$ by using a plunger pump $\left(120^{\circ} \mathrm{C}, 0.20 \mathrm{~mL} / \mathrm{min}\right)$. After a steady state was reached, the product solution was collected (10 $\mathrm{min})$. Then, the monolithic reactor was washed with THF $(30 \mathrm{~mL})$. Fifteen cycles of reactions and washings were carried out in the same way. The yields of the product were determined by a GC analysis. The results were summarized in Table 4 .

\section{Conclusions}

An efficient synthetic method of unsymmetrical biaryls was developed by integrating lithiation, borylation, and Suzuki-Miyaura coupling using a flow reactor packed a Pd catalyst supported by the polymer monolith. In addition, a series connection of the flow reactors was proved to be a method for the numbering-up of the flow reactors for a scale-up. The method was successfully applied to various coupling reactions including the synthesis of adapalene. Because both the series connection approach and the conventional parallel connection approach have practical limits of the number of reactors, both approaches will hopefully work together to affect large-scale productions in a continuous flow mode in the industry.

Supplementary Materials: The following are available online at http:/ /www.mdpi.com/2073-4344/9/3/300/s1, Figure S1: ${ }^{1} \mathrm{H}$ NMR spectrum of biphenyl-4-carbonitrile. Figure S2: ${ }^{1} \mathrm{H}$ NMR spectrum of methyl 4-phenylbenzoate. Figure S3: ${ }^{1} \mathrm{H}$ NMR spectrum of biphenyl. Figure S4: ${ }^{1} \mathrm{H}$ NMR spectrum of 4-methoxybiphenyl. Figure S5: ${ }^{1} \mathrm{H}$ NMR spectrum of 2-phenylthiophene. Figure S6: ${ }^{1} \mathrm{H}$ NMR spectrum of 4,4'-dicyanobiphenyl. Figure S7: ${ }^{1} \mathrm{H}$ NMR spectrum of 3,4'-dicyanobiphenyl. Figure S8: ${ }^{13} \mathrm{C}$ NMR spectrum of $3,4^{\prime}$-dicyanobiphenyl. Figure S9: ${ }^{1} \mathrm{H}$ NMR spectrum of 2,4'-dicyanobiphenyl. Figure S10: ${ }^{13} \mathrm{C}$ NMR spectrum of 2,4'-dicyanobiphenyl. Figure S11: ${ }^{1} \mathrm{H}$ NMR spectrum of methyl 4-(4-cyanophenyl)benzoate. Figure S12: ${ }^{1} \mathrm{H}$ NMR spectrum of methyl 4-(3-cyanophenyl)benzoate. Figure S13: ${ }^{13} \mathrm{C}$ NMR spectrum of methyl 4-(3-cyanophenyl)benzoate. Figure S14: ${ }^{1} \mathrm{H}$ NMR spectrum of methyl 4-(2-cyanophenyl)benzoate. Figure S15: ${ }^{1} \mathrm{H}$ NMR spectrum of 1-cyano-4"-bromo-4, $1^{\prime}: 4^{\prime}, 1^{\prime \prime}$-terphenylene. Figure S16: ${ }^{1} \mathrm{H}$ NMR spectrum of 2,2'-bithiophene. Figure S17: ${ }^{1} \mathrm{H}$ NMR spectrum of 4-(thiophen-2-yl)benzonitrile. Figure S18: ${ }^{1} \mathrm{H}$ NMR spectrum of methyl 4-(thiophen-2-yl)benzoate. Figure S19: ${ }^{1} \mathrm{H}$ NMR spectrum of 2-cyano-4'-formylbiphenyl. Figure S20: ${ }^{1} \mathrm{H}$ NMR spectrum of 2,2'-dicyanobiphenyl. Figure S21: ${ }^{1} \mathrm{H}$ NMR spectrum of methyl 2-(2-cyanophenyl)benzoate. Figure S22: ${ }^{13} \mathrm{C}$ NMR spectrum of methyl 2-(2-cyanophenyl)benzoate. Figure S23: ${ }^{1} \mathrm{H}$ NMR spectrum of methyl 6-iodo-2-naphthoate. Figure S24: ${ }^{13} \mathrm{C}$ NMR spectrum of methyl 6-iodo-2-naphthoate. Figure S25: ${ }^{1} \mathrm{H}$ NMR spectrum of methyl 6-(3-(1-adamantyl)-4-methoxyphenyl)-2-naphthoate. Figure S26: ${ }^{1} \mathrm{H}$ NMR spectrum of 6-(3-(1-adamantyl)-4-methoxyphenyl)-2-naphthoic acid (Adapalene). Table S1: List of product retention times in GC Analysis.

Author Contributions: Conceptualization, methodology, supervision, project administration and funding acquisition, A.N. and J.-i.Y.; investigation, K.H., Y.M., M.T., Y.T., K.M. (Koji Mitamura), K.M. (Kimihiro Matsukawa), N.I. and A.N.; writing—original draft preparation, A.N. and J.-i.Y.; writing—review and editing, M.T., Y.T. and A.N.

Funding: This work was partially supported by the Grant-in-Aid for Scientific Research on Innovative Areas 2707 Middle molecular strategy from MEXT (no. 15H05849), Scientific Research (B) (no. 26288049), Scientific Research (S) (no. 26220804), Scientific Research (S) (no. 25220913), Scientific Research (C) (no. 17865428), AMED (no. 18061567), the Japan Science and Technology Agency's (JST) A-step program (no. 18067420), CREST, and the Ogasawara Foundation for the Promotion of Science \& Engineering.

Conflicts of Interest: The authors declare no conflict of interest.

\section{References}

1. Ehrfeld, W.; Hessel, V.; Löwe, H. Microreactors; Wiley-VCH: Weinheim, Germany, 2000.

2. Hessel, V.; Hardt, S.; Löwe, H. Chemical Micro Process Engineering; Wiley-VCH: Weinheim, Germany, 2004.

3. Hessel, V.; Renken, A.; Schouten, J.C.; Yoshida, J. Micro Precess Engineering; Wiley-Blackwell: Chichester, UK, 2009.

4. Wirth, T. Microreactors in Organic Chemistry and Catalysis; Wiley: New York, NY, USA, 2013. 
5. Jähnisch, K.; Hessel, V.; Löwe, H.; Baerns, M. Chemistry in microstructured reactors. Angew. Chem. Int. Ed. 2004, 43, 406-446. [CrossRef]

6. Doku, G.N.; Verboom, W.; Reinhoudt, D.N.; Van den Berg, A. On-microchip multiphase chemistry-A review of microreactor design principles and reagent contacting modes. Tetrahedron 2005, 61, $2733-2742$. [CrossRef]

7. Yoshida, J.; Nagaki, A.; Iwasaki, T.; Suga, S. Enhancement of chemical selectivity by microreactors. Chem. Eng. Technol. 2005, 28, 259-266. [CrossRef]

8. Watts, P.; Haswell, S.J. The application of micro reactors for organic synthesis. Chem. Soc. Rev. 2005, 34, 235-246. [CrossRef]

9. Geyer, K.; Codée, J.D.C.; Seeberger, P.H. Microreactors as tools for synthetic Chemists-the chemists' round-bottomed flask of the 21st century? Chem. Eur. J. 2006, 12, 8434-8442. [CrossRef]

10. DeMello, A.J. Control and detection of chemical reactions in microfluidic systems. Nature 2006, 442, $394-402$. [CrossRef]

11. Song, H.; Chen, D.L.; Ismagilov, R.F. Reactions in droplets in microfluidic channels. Angew. Chem. Int. Ed. 2006, 45, 7336-7356. [CrossRef]

12. Kobayashi, J.; Mori, Y.; Kobayashi, S. Multiphase organic synthesis in microchannel reactors. Chem. Asian J. 2006, 1, 22-35. [CrossRef]

13. Brivio, M.; Verboom, W.; Reinhoudt, D.N. Miniaturized continuous flow reaction vessels: influence on chemical reactions. Lab Chip 2006, 6, 329-344. [CrossRef]

14. Mason, B.P.; Price, K.E.; Steinbacher, J.L.; Bogdan, A.R.; McQuade, D.T. Greener approaches to organic synthesis using microreactor technology. Chem. Rev. 2007, 107, 2300-2318. [CrossRef]

15. Ahmed-Omer, B.; Brandt, J.C.; Wirth, T. Advanced organic synthesis using microreactor technology. Org. Biomol. Chem. 2007, 5, 733-740. [CrossRef] [PubMed]

16. Watts, P.; Wiles, C. Recent advances in synthetic micro reaction technology. Chem. Commun. 2007, 443-467. [CrossRef]

17. Fukuyama, T.; Rahman, M.T.; Sato, M.; Ryu, I. Adventures in inner space: microflow systems for practical organic synthesis. Synlett 2008, 151-163. [CrossRef]

18. Hartman, R.L.; Jensen, K.F. Microchemical systems for continuous-flow synthesis. Lab Chip 2009, 9, $2495-2507$. [CrossRef]

19. McMullen, J.P.; Jensen, K.F. Integrated microreactors for reaction automation: new approaches to reaction development. Annu. Rev. Anal. Chem. 2010, 3, 19-42. [CrossRef]

20. Yoshida, J.; Kim, H.; Nagaki, A. Green and sustainable chemical synthesis using flow microreactors. ChemSusChem 2011, 4, 331-340. [CrossRef] [PubMed]

21. Wiles, C.; Watts, P. Continuous flow reactors: a perspective. Green Chem. 2012, 14, 38-54. [CrossRef]

22. Kirschning, A.; Kupracz, L.; Hartwig, J. New synthetic opportunities in miniaturized flow reactors with inductive heating. Chem. Lett. 2012, 41,562-570. [CrossRef]

23. Elvira, K.S.; iSolvas, X.C.; Wootton, R.C.R.; DeMello, A.J. The past, present and potential for microfluidic reactor technology in chemical synthesis. Nat. Chem. 2013, 5, 905-915. [CrossRef]

24. Pastre, J.C.; Browne, D.L.; Ley, S.V. Flow chemistry syntheses of natural products. Chem. Soc. Rev. 2013, 42, 8849-8869. [CrossRef] [PubMed]

25. Baxendale, I.R. The integration of flow reactors into synthetic organic chemistry. J. Chem. Technol. Biotechnol. 2013, 88, 519-552. [CrossRef]

26. Fukuyama, T.; Totoki, T.; Ryu, I. Carbonylation in microflow: close encounters of CO and reactive species. Green Chem. 2014, 16, 2042-2050. [CrossRef]

27. Gutmann, B.; Cantillo, D.; Kappe, C.O. Continuous-flow technology-A tool for the safe manufacturing of active pharmaceutical ingredients. Angew. Chem. Int. Ed. 2015, 54, 6688-6728. [CrossRef]

28. Porta, R.; Benaglia, M.; Puglisi, A. Flow chemistry: Recent developments in the synthesis of pharmaceutical products. Org. Process Res. Dev. 2016, 20, 2-25. [CrossRef]

29. Gemoets, H.P.L.; Su, Y.; Shang, M.; Hessel, V.; Luque, R.; Noel, T. Liquid phase oxidation chemistry in continuous-flow microreactors. Chem. Soc. Rev. 2016, 45, 83-117. [CrossRef]

30. Plutschack, M.B.; Pieber, B.; Gilmore, K.; Seeberger, P.H. The hitchhiker's guide to floe chemistry. Chem. Rev. 2017, 117, 11796-11893. [CrossRef] [PubMed] 
31. Cantillo, D.; Baghbanzadeh, M.; Kappe, C.O. In situ generated iron oxide nanocrystals as efficient and selective catalysts for the reduction of nitroarenes using a continuous flow method. Angew. Chem. Int. Ed. 2012, 51, 10190-10193. [CrossRef]

32. Shu, W.; Buchwald, S.L. Enantioselective $\beta$-arylation of ketones enabled by lithiation/borylation/ 1,4-addition sequence under flow conditions. Angew. Chem. Int. Ed. 2012, 51, 5355-5358. [CrossRef]

33. Lévesque, F.; Seeberger, P.H. Continuous-flow synthesis of the anti-malaria drug artemisinin. Angew. Chem. Int. Ed. 2012, 51, 1706-1709. [CrossRef]

34. Basavaraju, K.C.; Sharma, S.; Maurya, R.A.; Kim, D.P. Safe use of a toxic compound: Heterogeneous $\mathrm{OsO}_{4}$ catalysis in a nanobrush polymer microreactor. Angew. Chem. Int. Ed. 2013, 52, 6735-6738. [CrossRef]

35. Brancour, C.; Fukuyama, T.; Mukai, Y.; Skrydstrup, T.; Ryu, I. Modernized low pressure carbonylation methods in batch and flow employing common acids as a CO source. Org. Lett. 2013, 15, $2794-2797$. [CrossRef] [PubMed]

36. Nguyen, J.D.; Reiß, B.; Dai, C.; Stephenson, C.R.J. Batch to flow deoxygenation using visible light photoredox catalysis. Chem. Commun. 2013, 49, 4352-4354. [CrossRef]

37. Battilocchio, C.; Hawkins, J.M.; Ley, S.V. A Mild and efficient flow procedure for the transfer hydrogenation of ketones and aldehydes using hydrous zirconia. Org. Lett. 2013, 15, 2278-2281. [CrossRef]

38. Kleinke, A.S.; Jamison, T.F. Hydrogen-fee alkene reduction in continuous flow. Org. Lett. 2013, 15, 710-713. [CrossRef]

39. Asano, K.; Uesugi, Y.; Yoshida, J. Pauson-Khand reactions in a photochemical flow microreactor. Org. Lett. 2013, 15, 2398-2401. [CrossRef] [PubMed]

40. Guetzoyan, L.; Nikbin, N.; Baxendale, I.R.; Ley, S.V. Flow chemistry synthesis of zolpidem, alpidem and other GABAA agonists and their biological evaluation through the use of in-line frontal affinity chromatography. Chem. Sci. 2013, 4, 764-769. [CrossRef]

41. Fuse, S.; Mifune, Y.; Takahashi, T. Efficient amide bond formation through a rapid and strong activation of carboxylic acids in a microflow reactor. Angew. Chem. Int. Ed. 2014, 53, 851-855. [CrossRef] [PubMed]

42. He, Z.; Jamison, T.F. Continuous-flow synthesis of functionalized phenols by aerobic oxidation of Grignard reagents. Angew. Chem. Int. Ed. 2014, 53, 3353-3357. [CrossRef]

43. Nagaki, A.; Takahashi, Y.; Yoshida, J. Extremely fast gas/liquid reactions in flow microreactors: Carboxylation of short-lived organolithiums. Chem. Eur. J. 2014, 20, 7931-7934. [CrossRef]

44. Chen, M.; Ichikawa, S.; Buchwald, S.L. Rapid and efficient copper-catalyzed finkelstein reaction of (hetero)aromatics under continuous-flow conditions. Angew. Chem. Int. Ed. 2015, 54, 263-266. [CrossRef]

45. Nagaki, A.; Takahashi, Y.; Yoshida, J. Generation and reaction of carbamoyl anions in flow: Applications in the three-component synthesis of functionalized $\alpha$-ketoamides. Angew. Chem. Int. Ed. 2016, 55, 5327-5331. [CrossRef] [PubMed]

46. Fuse, S.; Mifune, Y.; Nakamura, H.; Tanaka, H. Total synthesis of feglymycin based on a linear/convergent hybrid approach using micro-flow amide bond formation. Nat. Commun. 2016, 7, 13491. [CrossRef] [PubMed]

47. Seo, H.; Katcher, M.H.; Jamison, T.F. Photoredox activation of carbon dioxide for amino acid synthesis in continuous flow. Nat. Chem. 2017, 9, 453-456. [CrossRef] [PubMed]

48. Nagaki, A.; Kim, H.; Yoshida, J. Aryllithium compounds bearing alkoxycarbonyl groups. Generation and reactions using a microflow system. Angew. Chem. Int. Ed. 2008, 47, 7833-7836. [CrossRef]

49. Nagaki, A.; Kim, H.; Yoshida, J. Nitro-substituted aryl lithium compounds in microreactor synthesis: Switch between kinetic and thermodynamic control. Angew. Chem. Int. Ed. 2009, 48, 8063-8065. [CrossRef] [PubMed]

50. Nagaki, A.; Kim, H.; Moriwaki, Y.; Matsuo, C.; Yoshida, J. A flow microreactor system enables organolithium reactions without protecting alkoxycarbonyl groups. Chem. Eur. J. 2010, 16, 11167-11177. [CrossRef]

51. Kim, H.; Nagaki, A.; Yoshida, J. A flow-microreactor approach to protecting-group-free synthesis using organolithium compounds. Nat. Commun. 2011, 2, 264. [CrossRef]

52. Tomida, Y.; Nagaki, A.; Yoshida, J. Asymmetric carbolithiation of conjugated enynes: A flow microreactor enables the use of configurationally unstable intermediates before they epimerize. J. Am. Chem. Soc. 2011, 133, 3744-3747. [CrossRef]

53. Nagaki, A.; Matsuo, C.; Kim, S.; Saito, K.; Miyazaki, A.; Yoshida, J. Lithiation of 1,2-dichloroethene in flow microreactors: Versatile synthesis of alkenes and alkynes by precise residence-time control. Angew. Chem. Int. Ed. 2012, 51, 3245-3248. [CrossRef] 
54. Nagaki, A.; Ichinari, D.; Yoshida, J. Three-Component coupling based on flash chemistry. Carbolithiation of benzyne with functionalized aryllithiums followed by reactions with electrophiles. J. Am. Chem. Soc. 2014, 136, 12245-12248. [CrossRef] [PubMed]

55. Nagaki, A.; Tsuchihashi, Y.; Haraki, S.; Yoshida, J. Benzyllithiums bearing aldehyde carbonyl groups. A flash chemistry approach. Org. Biomol. Chem. 2015, 13, 7140-7145. [CrossRef]

56. Nagaki, A.; Imai, K.; Ishiuchi, S.; Yoshida, J. Reactions of difunctional electrophiles with functionalized aryllithium compounds: Remarkable chemoselectivity by flash chemistry. Angew. Chem. Int. Ed. 2015, 54, 1914-1918. [CrossRef]

57. Nagaki, A.; Kim, S.; Miuchi, N.; Yamashita, H.; Hirose, K.; Yoshida, J. Switching between intermolecular and intramolecular reactions using flow microreactors: Lithiation of 2-bromo-2'-silylbiphenyls. Org. Chem. Front. 2016, 3, 1250-1253. [CrossRef]

58. Yoshida, J.; Kim, H.; Nagaki, A. "Impossible" chemistries based on flow and micro. J. Flow. Chem. 2017, 7, 60-64. [CrossRef]

59. Diederich, F.; Stang, P.J. Metal-Catalyzed Cross-Coupling Reactions; Wiley-VCH: New York, NY, USA, 1998.

60. Stanforth, S.P. Catalytic cross-coupling reactions in biaryl synthesis. Tetrahedron 1998, 54, 263-303. [CrossRef]

61. Hassan, J.; Sévignon, M.; Gozzi, C.; Schulz, E.; Lemaire, M. Aryl-aryl bond formation one century after the discovery of the ullmann reaction. Chem. Rev. 2002, 102, 1359-1470. [CrossRef]

62. Johansson Seechurn, C.C.C.; Kitching, M.O.; Colacot, T.J.; Snieckus, V. Palladium-catalyzed cross-coupling: A historical contextual perspective to the 2010 Nobel Prize. Angew. Chem. Int. Ed. 2012, 51, 5062-5085. [CrossRef]

63. Gildner, P.G.; Thomas, J. Colacot, T.J. Reactions of the 21st century: Two decades of innovative catalyst design for palladium-catalyzed cross-couplings. Organometallics 2015, 34, 5497-5508. [CrossRef]

64. Roy, D.; Uozumi, Y. Recent advances in palladium-catalyzed cross-coupling reactions at ppm to ppb molar catalyst loadings. Adv. Synth. Catal. 2018, 360, 602-625. [CrossRef]

65. Mennecke, K.; Sodolenko, W.; Kirschning, A. Carbon-carbon cross-coupling reactions under continuous flow conditions using poly(vinylpyridine) doped with palladium. Synthesis 2008, 1589-1599. [CrossRef]

66. Muñoz, J.M.; Alcázar, J.; de la Hoz, A.; Díaz-Ortiz, A. Cross-coupling in flow using supported catalysts: Mild, clean, efficient and sustainable Suzuki-Miyaura coupling in a single pass. Adv. Synth. Catal. 2012, 354, 3456-3460. [CrossRef]

67. Pavia, C.; Ballerini, E.; Bivona, L.A.; Giacalone, F.; Aprile, C.; Vaccaro, L.; Gruttadauria, M. Palladium supported on cross-linked imidazolium network on silica as highly sustainable catalysts for the Suzuki reaction under flow conditions. Adv. Synth. Catal. 2013, 355, 2007-2018. [CrossRef]

68. Tanimu, A.; Jaenicke, S.; Alhooshani, K. Heterogeneous catalysis in continuous flow microreactors: A review of methods and applications. Chem. Eng. J. 2017, 327, 792-821. [CrossRef]

69. Masuda, K.; Ichitsuka, T.; Koumura, N.; Sato, K.; Kobayashi, S. Flow fine synthesis with heterogeneous catalysts. Tetrahedron 2018, 74, 1705-1730. [CrossRef]

70. Solodenko, W.; Wen, H.; Leue, S.; Stuhlmann, F.; Sourkouni-Argirusi, G.; Jas, G.; Schönfeld, H.; Kunz, U.; Kirschning, A. Development of a continuous-flow system for catalysis with palladium(0) particles. Eur. J. Org. Chem. 2004, 3601-3610. [CrossRef]

71. Kunz, U.; Kirschning, A.; Wen, H.L.; Solodenko, W.; Cecilia, R.; Kappe, C.O.; Turek, T. Monolithic polymer/carrier materials: Versatile composites for fine chemical synthesis. Catal. Today 2005, 105, 318-324. [CrossRef]

72. Michrowska, A.; Mennecke, K.; Kunz, U.; Kirschning, A.; Grela, K. A new concept for the noncovalent binding of a ruthenium-based olefin metathesis catalyst to polymeric phases: Preparation of a catalyst on raschig rings. J. Am. Chem. Soc. 2006, 128, 13261-13267. [CrossRef]

73. Nikbin, N.; Ladlow, M.; Ley, S.V. Continuous flow ligand-free heck reactions using monolithic Pd [0] nanoparticles. Org. Process Res. Dev. 2007, 11, 458-462. [CrossRef]

74. Mennecke, K.; Cecilia, R.; Glasnov, T.N.; Gruhl, S.; Vogt, C.; Feldhoff, A.; Vargas, M.A.L.; Kappe, C.O.; Kunz, U.; Kirschning, A. Palladium(0) nanoparticles on glass-polymer composite materials as recyclable catalysts: A comparison study on their use in batch and continuous flow processes. Adv. Synth. Catal. 2008, 350, 717-730. [CrossRef]

75. Kundu, D.; Patra, A.K.; Sakamoto, J.; Uyama, H. A palladium-loaded mesoporous polymer monolith as reusable heterogeneous catalyst for cross-coupling reactions. React. Funct. Polym. 2014, 79, 8-13. [CrossRef] 
76. Cantillo, D.; Kappe, C.O. Immobilized transition metals as catalysts for cross-couplings in continuous flow-A critical assessment of the reaction mechanism and metal leaching. ChemCatChem 2014, 6, 3286-3305. [CrossRef]

77. Munirathinam, R.; Huskens, J.; Verboom, W. Supported catalysis in continuous-flow microreactors. Adv. Synth. Catal. 2015, 357, 1093-1123. [CrossRef]

78. Ramarao, C.; Ley, S.V.; Smith, S.C.; Shirley, I.M.; DeAlmeida, N. Encapsulation of palladium in polyurea microcapsules. Chem. Commun. 2002, 1132-1133. [CrossRef]

79. Lee, C.K.Y.; Holmes, A.B.; Ley, S.V.; McConvey, I.F.; Al-Duri, B.; Leeke, G.A.; Santos, R.C.D.; Seville, J.P.K. Efficient batch and continuous flow Suzuki cross-coupling reactions under mild conditions, catalysed by polyurea-encapsulated palladium (II) acetate and tetra-n-butylammonium salts. Chem. Commun. 2005, 2175-2177. [CrossRef]

80. Baxendale, I.R.; Griffiths-Jones, C.M.; Ley, S.V.; Tranmer, G.K. Microwave-assisted Suzuki coupling reactions with an encapsulated palladium catalyst for batch and continuous-flow transformations. Chem. Eur. J. 2006, 12, 4407-4416. [CrossRef]

81. Phan, N.T.S.; Brown, D.H.; Styring, P. A facile method for catalyst immobilisation on silica: nickel-catalysed Kumada reactions in mini-continuous flow and batch reactors. Green Chem. 2004, 6, 526-532. [CrossRef]

82. Al-Hashimi, M.; Qazi, A.; Sullivan, A.C.; Wilson, J.R.H. Dithio palladium modified silicas-New heterogeneous catalysts for Suzuki cross-coupling reactions. J. Mol. Catal. A 2007, 278, 160-164. [CrossRef]

83. Lim, J.; Riduan, S.N.; Lee, S.S.; Ying, J.Y. Siliceous mesocellular foam-supported aza(bisoxazoline)-copper catalysts. Adv. Synth. Catal. 2008, 350, 1295-1308. [CrossRef]

84. Polshettiwar, V.; Len, C.; Fihri, A. Silica-supported palladium: Sustainable catalysts for cross-coupling reactions. Coord. Chem. Rev. 2009, 253, 2599-2626. [CrossRef]

85. Ceylan, S.; Friese, C.; Lammel, C.; Mazac, K.; Kirschning, A. Inductive heating for organic synthesis by using functionalized magnetic nanoparticles inside microreactors. Angew. Chem. Int. Ed. 2008, 47, 8950-8953. [CrossRef] [PubMed]

86. Laska, U.; Frost, C.G.; Price, G.J.; Plucinski, P.K. Easy-separable magnetic nanoparticle-supported Pd catalysts: Kinetics, stability and catalyst re-use. J. Catal. 2009, 268, 318-328. [CrossRef]

87. Houlding, T.K.; Gao, P.; Degirmenci, V.; Tchabanenko, K.; Rebrov, E.V. Mechanochemical synthesis of $\mathrm{TiO}_{2} / \mathrm{NiFe}_{2} \mathrm{O}_{4}$ magnetic catalysts for operation under RF field. Mater. Sci. Eng. B 2015, 193, 175-180. [CrossRef]

88. Miyaura, N.; Suzuki, A. Palladium-catalyzed cross-coupling reactions of organoboron compounds. Chem. Rev. 1995, 95, 2457-2483. [CrossRef]

89. Kotha, S.; Lahiri, K.; Kashinath, D. Recent applications of the Suzuki-Miyaura cross-coupling reaction in organic synthesis. Tetrahedron 2002, 58, 9633-9695. [CrossRef]

90. Maluenda, I.; Navarro, O. Recent developments in the Suzuki-Miyaura reaction: 2010-2014. Molecules 2015, 20, 7528-7557. [CrossRef]

91. Chatterjee, A.; Ward, T.R. Recent advances in the palladium catalyzed Suzuki-Miyaura cross-coupling reaction in water. Catal. Lett. 2016, 146, 820-840. [CrossRef]

92. Ishiyama, T.; Itoh, Y.; Kitano, T.; Miyaura, N. Synthesis of arylboronates via the palladium(0)-catalyzed cross-coupling reaction of tetra(alkoxo)diborons with aryl triflates. Tetrahedron Lett. 1997, 38, 3447-3450. [CrossRef]

93. Giroux, A.; Han, Y.; Prasit, P. One pot biaryl synthesis via in situ boronate formation. Tetrahedron Lett. 1997, 38, 3841-3844. [CrossRef]

94. Ishiyama, T.; Miyaura, N. Chemistry of Group 13 element-transition metal linkage-The platinum- and palladium-catalyzed reactions of (alkoxo)diborons. J. Organomet. Chem. 2000, 611, 392-402. [CrossRef]

95. Willis, D.M.; Strongin, R.M. Palladium-catalyzed borylation of aryldiazonium tetrafluoroborate salts. A new synthesis of arylboronic esters. Tetrahedron Lett. 2000, 41, 8683-8686. [CrossRef]

96. Todd, M.H.; Abell, C. Novel chemical tagging method for combinatorial synthesis utilizing suzuki chemistry and fourier transform ion cyclotron resonance mass spectrometry. J. Comb. Chem. 2001, 3, 319-327. [CrossRef] [PubMed]

97. Fürstner, A.; Seidel, G. Microwave-assisted synthesis of pinacol boronates from aryl chlorides catalyzed by a palladium/imidazolium salt system. Org. Lett. 2002, 4, 541-543. [CrossRef] 
98. Billingsley, K.L.; Barder, T.E.; Buchwald, S.L. Palladium-catalyzed borylation of aryl chlorides: Scope, applications, and computational studies. Angew. Chem. Int. Ed. 2007, 46, 5359-5363. [CrossRef] [PubMed]

99. Mo, F.; Jiang, Y.; Qiu, D.; Zhang, Y.; Wang, J. Direct conversion of arylamines to pinacol boronates: A metal-free borylation process. Angew. Chem. Int. Ed. 2010, 49, 1846-1849. [CrossRef] [PubMed]

100. Maddaford, S.P.; Keay, B.A. Scope and limitations of the palladium-catalyzed cross-coupling reaction of in situ generated organoboranes with aryl and vinyl halides. J. Org. Chem. 1994, 59, 6501-6503. [CrossRef]

101. Andersen, N.G.; Maddaford, S.P.; Keay, B.A. A modified in situ Suzuki cross-coupling of haloarenes for the preparation of C2-symmetric biaryls. J. Org. Chem. 1996, 61, 9556-9559. [CrossRef]

102. Brown, S.D.; Armstrong, R.W. Synthesis of tetrasubstituted ethylenes on solid support via resin capture. J. Am. Chem. Soc. 1996, 118, 6331-6332. [CrossRef]

103. Carbonnelle, A.C.; Zhu, J. A novel synthesis of biaryl-containing macrocycles by a domino Miyaura arylboronate formation: Intramolecular Suzuki reaction. Org. Lett. 2000, 2, 3477-3480. [CrossRef]

104. Li, W.; Nelson, D.P.; Jensen, M.S.; Hoerrner, R.S.; Cai, D.; Larsen, R.D.; Reider, P.J. An improved protocol for the preparation of 3-pyridyl- and some arylboronic acids. J. Org. Chem. 2002, 67, 5394-5397. [CrossRef]

105. Zhu, L.; Duquette, J.; Zhang, M. An improved preparation of arylboronates: application in one-pot Suzuki biaryl synthesis. J. Org. Chem. 2003, 68, 3729-3732. [CrossRef]

106. Shu, W.; Pellegatti, L.; Oberli, M.A.; Buchwald, S.L. Continuous-flow synthesis of biaryls enabled by multistep solid-handling in a lithiation/borylation/Suzuki-Miyaura cross-coupling sequence. Angew. Chem. Int. Ed. 2011, 50, 10665-10669. [CrossRef] [PubMed]

107. Yoshida, J. Flash Chemistry. Fast Organic Synthesis in Microsystems; Wiley-Blackwell: Chichester, UK, 2008.

108. Yoshida, J. Flash chemistry using electrochemical method and microsystems. Chem. Commun. 2005, 4509-4516. [CrossRef]

109. Yoshida, J.; Nagaki, A.; Yamada, T. Flash chemistry: fast chemical synthesis by using microreactors. Chem. Eur. J. 2008, 14, 7450-7459. [CrossRef] [PubMed]

110. Yoshida, J. Flash chemistry: flow microreactor synthesis based on high-resolution reaction time control. Chem. Rec. 2010, 10, 332-341. [CrossRef] [PubMed]

111. Yoshida, J.; Takahashi, Y.; Nagaki, A. Flash chemistry: flow chemistry that cannot be done in batch. Chem. Commun. 2013, 49, 9896-9904. [CrossRef]

112. Fujita, T.; Konno, N.; Watabe, Y.; Ichitsuka, T.; Nagaki, A.; Yoshida, J.; Ichikawa, J. Flash generation and borylation of 1-(trifluoromethyl)vinyllithium toward synthesis of $\alpha$-(trifluoromethyl)styrenes. J. Fluorine Chem. 2018, 207, 72-76. [CrossRef]

113. Nagaki, A.; Moriwaki, Y.; Yoshida, J. Flow synthesis of arylboronic esters bearing electrophilic functional groups and space integration with Suzuki-Miyaura coupling without intentionally added base. Chem. Commun. 2012, 48, 11211-11213. [CrossRef] [PubMed]

114. Comer, E.; Organ, M.G. A microcapillary system for simultaneous, parallel microwave-assisted synthesis. Chem. Eur. J. 2005, 11, 7223-7227. [CrossRef] [PubMed]

115. Gömann, A.; Deverell, J.A.; Munting, K.F.; Jones, R.C.; Rodemann, T.; Canty, A.J.; Smith, J.A.; Guijt, R.M. Palladium-mediated organic synthesis using porous polymer monolith formed in situ as a continuous catalyst support structure for application in microfluidic devices. Tetrahedron 2009, 65, 1450-1454. [CrossRef]

116. He, P.; Haswell, S.J.; Fletcher, P.D.I.; Kelly, S.M.; Mansfield, A. Scaling up of continuous-flow, microwave-assisted, organic reactions by varying the size of Pd-functionalized catalytic monoliths. Beilstein J. Org. Chem. 2011, 7, 1150-1157. [CrossRef] [PubMed]

117. Reynolds, W.R.; Plucinski, P.; Frost, C.G. Robust and reusable supported palladium catalysts for cross-coupling reactions in flow. Catal. Sci. Technol. 2014, 4, 948-954. [CrossRef]

118. Chiroli, V.; Benaglia, M.; Puglisi, A.; Porta, R.; Jumde, R.P.; Mandoli, A. A chiral organocatalytic polymer-based monolithic reactor. Green Chem. 2014, 16, 2798-2806. [CrossRef]

119. Jumde, R.P.; Marelli, M.; Scotii, N.; Mandoli, A.; Psaro, R.; Evangelisti, C. Ultrafine palladium nanoparticles immobilized into poly(4-vinylpyridine)-based porous monolith for continuous-flow Mizoroki-Heck reaction. J. Mol. Catal. A 2016, 414, 55-61. [CrossRef]

120. Suga, S.; Yamada, D.; Yoshida, J. Cationic three-component coupling involving an optically active enamine derivative. From time integration to space integration of reactions. Chem. Lett. 2010, 39, 404-406. [CrossRef] 
121. Nagaki, A.; Kenmoku, A.; Moriwaki, Y.; Hayashi, A.; Yoshida, J. Cross-coupling in a flow microreactor. Space integration of lithiation and Murahashi coupling. Angew. Chem. Int. Ed. 2010, 49, 7543-7547. [CrossRef] [PubMed]

122. Yoshida, J.; Saito, K.; Nokami, T.; Nagaki, A. Space integration of reactions: An approach to increase capability of organic synthesis. Synlett 2011, 1189-1194. [CrossRef]

123. Nagaki, A.; Hirose, K.; Moriwaki, Y.; Mitamura, K.; Matsukawa, K.; Ishizuka, N.; Yoshida, J. Integration of borylation of aryllithiums and Suzuki-Miyaura coupling using monolithic Pd catalyst. Catal. Sci. Technol. 2016, 6, 4690-4694. [CrossRef]

124. Nagaki, A.; Kim, H.; Usutani, H.; Matsuo, C.; Yoshida, J. Generation and reaction of cyano-substituted aryllithium compounds using microreactors. Org. Biomol. Chem. 2010, 8, 1212-1217. [CrossRef]

125. Nagaki, A.; Takabayashi, N.; Tomida, Y.; Yoshida, J. Synthesis of unsymmetrical biaryls by means of mono-selective reaction of polyhaloarenes using integrated microflow system. Org. Lett. 2008, 10, 3937-3940. [CrossRef]

126. Hessel, V.; Hardt, S.; Loewe, H. Chemical Micro Process Engineering: Fundamentals, Modelling and Reactions; Wiley-VCH: Weinheim, Germany, 2005.

127. Löwe, H.; Ziogas, A. Numbering-up of micro devices: a first liquid-flow splitting unit. Chem. Eng. J. 2004, 101, 421-429.

128. Anderson, N.G. Using continuous processes to increase production. Org. Process Res. Dev. 2012, 16, 852-869. [CrossRef]

129. Nagaki, A.; Hirose, K.; Tonomura, O.; Taniguchi, S.; Taga, T.; Hasebe, S.; Ishizuka, N.; Yoshida, J. Design of a numbering-up system of monolithic microreactors and its application to synthesis of a key intermediate of valsartan. Org. Process Res. Dev. 2016, 20, 687-691. [CrossRef]

130. Su, Y.; Kuijpers, K.; Hessel, V.; Noël, T. A convenient numbering-up strategy for the scale-up of gas-liquid photoredox catalysis in flow. React. Chem. Eng. 2016, 1, 73-81. [CrossRef]

131. Commenge, J.M.; Falk, L.; Corriou, J.P.; Matlosz, M. Optimal design for flow uniformity in microchannel reactors. AIChE J. 2002, 48, 345-358. [CrossRef]

132. Tonomura, O.; Tominari, T.; Kano, M.; Hasebe, S. Operation policy for micro chemical plants with external numbering-up structure. Chem. Eng. J. 2008, 135, S131-S137. [CrossRef]

133. Amador, C.; Gavriilidis, A.; Angeli, P. Flow distribution in different microreactor scale-out geometries and the effect of manufacturing tolerances and channel blockage. Chem. Eng. J. 2004, 101, 379-390. [CrossRef]

134. Wang, J. Theory of flow distribution in manifolds. Chem. Eng. J. 2011, 168, 1331-1345. [CrossRef]

135. Won, J.W.; Park, K.M.; Choi, S.J.; Chang, P. Serial connection of packed-bed reactors with different reaction temperatures: enhanced operational stability for enzymatically interesterified trans-free lipid production. Eur. Food Res. Technol. 2012, 235, 647-657. [CrossRef]

136. Irvine, M.W.; Costa, B.M.; Dlaboga, D.; Culley, G.R.; Hulse, R.; Scholefield, C.L.; Atlason, P.; Fang, G.; Eaves, R.; Morley, R.; et al. Piperazine-2,3-dicarboxylic acid derivatives as dual antagonists of NMDA and GluK1-containing kainate receptors. J. Med. Chem. 2012, 55, 327-341. [CrossRef] [PubMed]

137. Grossman, O.; Gelman, D. Novel trans-spanned palladium complexes as efficient catalysts in mild and amine-free cyanation of aryl bromides under air. Org. Lett. 2006, 8, 1189-1191. [CrossRef]

138. Ackermann, L.; Gschrei, C.J.; Althammera, A.; Riederer, M. Cross-coupling reactions of aryl and vinyl chlorides catalyzed by a palladium complex derived from an air-stable H-phosphonate. Chem. Commun. 2006, 1419-1421. [CrossRef]

139. Bandari, R.; Höche, T.; Prager, A.; Dirnberger, K.; Buchmeiser, M.R. Ring-opening metathesis polymerization based pore-size-selective functionalization of glycidyl methacrylate based monolithic media: access to size-stable nanoparticles for ligand-free metal catalysis. Chem. Eur. J. 2010, 16, 4650-4658. [CrossRef] [PubMed]

140. Zhang, G. Efficient protocol for the phosphine-free Suzuki-Miyaura reaction catalyzed by palladium on carbon at room temperature. Synthesis 2005, 537-542. [CrossRef]

141. Kuhl, N.; Hopkinson, M.N.; Glorius, F. Selective rhodium(III)-catalyzed cross-dehydrogenative coupling of furan and thiophene derivatives. Angew. Chem. Int. Ed. 2012, 51, 8230-8234. [CrossRef] [PubMed]

142. Cahiez, G.; Chaboche, C.; Mahuteau-Betzer, F.; Ahr, M. Iron-catalyzed homo-coupling of simple and functionalized arylmagnesium reagents. Org. Lett. 2005, 7, 1943-1946. [CrossRef] [PubMed] 
143. Huang, Y.; Yang, C.; Yi, J.; Deng, X.; Fu, Y.; Liu, L. Cu-catalyzed carbon-heteroatom coupling reactions under mild conditions promoted by resin-bound organic ionic bases. J. Org. Chem. 2011, 76, 800-810. [CrossRef]

144. Amatore, M.; Gosmini, C. Efficient cobalt-catalyzed formation of unsymmetrical biaryl compounds and its application in the synthesis of a sartan intermediate. Angew. Chem. Int. Ed. 2008, 47, 2089-2092. [CrossRef]

145. Schiek, M.; Al-Shamerya, K.; Lützen, A. Synthesis of symmetrically and unsymmetrically para-functionalized p-ouaterphenylenes. Synthesis 2007, 613-621. [CrossRef]

146. Nising, C.F.; Schmid, U.K.; Nieger, M.; Bräse, S. A new protocol for the one-pot synthesis of symmetrical biaryls. J. Org. Chem. 2004, 69, 6830-6833. [CrossRef]

147. Chen, X.; Zhou, L.; Li, Y.; Xie, T.; Zhou, S. Synthesis of heteroaryl compounds through cross-coupling reaction of aryl bromides or benzyl halides with thienyl and pyridyl aluminum reagents. J. Org. Chem. 2014, 79, 230-239. [CrossRef]

148. Izquierdo, F.; Corpet, M.; Nolan, S.P. The Suzuki-Miyaura reaction performed using a palladiumN-heterocyclic carbene catalyst and a weak inorganic base. Eur. J. Org. Chem. 2015, 1920-1924. [CrossRef]

149. Kristensen, J.; Lysén, M.; Vedsø, P.; Begtrup, M. Synthesis of ortho substituted arylboronic esters by in situ trapping of unstable lithio intermediates. Org. Lett. 2001, 3, 1435-1437. [CrossRef] [PubMed]

150. Liu, Z.; Xiang, J. A high yield and pilot-scale process for the preparation of adapalene. Org. Process Res. Dev. 2006, 10, 285-288. [CrossRef]

(C) 2019 by the authors. Licensee MDPI, Basel, Switzerland. This article is an open access article distributed under the terms and conditions of the Creative Commons Attribution (CC BY) license (http://creativecommons.org/licenses/by/4.0/). 